\title{
CFD analysis of transpirational cooling by vegetation : case study for specific meteorological conditions during a heat wave in Arnhem, Netherlands
}

\section{Citation for published version (APA):}

Gromke, C. B., Blocken, B., Janssen, W. D., Merema, B., van Hooff, T., \& Timmermans, H. J. P. (2015). CFD analysis of transpirational cooling by vegetation : case study for specific meteorological conditions during a heat wave in Arnhem, Netherlands. Building and Environment, 83, 11-26.

https://doi.org/10.1016/j.buildenv.2014.04.022

\section{Document license:}

TAVERNE

DOI:

10.1016/j.buildenv.2014.04.022

Document status and date:

Published: 01/01/2015

\section{Document Version:}

Publisher's PDF, also known as Version of Record (includes final page, issue and volume numbers)

\section{Please check the document version of this publication:}

- A submitted manuscript is the version of the article upon submission and before peer-review. There can be important differences between the submitted version and the official published version of record. People interested in the research are advised to contact the author for the final version of the publication, or visit the DOI to the publisher's website.

- The final author version and the galley proof are versions of the publication after peer review.

- The final published version features the final layout of the paper including the volume, issue and page numbers.

Link to publication

\footnotetext{
General rights

- You may freely distribute the URL identifying the publication in the public portal. follow below link for the End User Agreement:

www.tue.nl/taverne

\section{Take down policy}

If you believe that this document breaches copyright please contact us at:

openaccess@tue.nl

providing details and we will investigate your claim.
}

Copyright and moral rights for the publications made accessible in the public portal are retained by the authors and/or other copyright owners and it is a condition of accessing publications that users recognise and abide by the legal requirements associated with these rights.

- Users may download and print one copy of any publication from the public portal for the purpose of private study or research.

- You may not further distribute the material or use it for any profit-making activity or commercial gain

If the publication is distributed under the terms of Article 25fa of the Dutch Copyright Act, indicated by the "Taverne" license above, please 


\title{
CFD analysis of transpirational cooling by vegetation: Case study for specific meteorological conditions during a heat wave in Arnhem, Netherlands
}

\author{
Christof Gromke ${ }^{\mathrm{a}, \mathrm{b}, *}$, Bert Blocken $^{\mathrm{a}, \mathrm{c}}$, Wendy Janssen $^{\mathrm{a}}$, Bart Merema ${ }^{\mathrm{a}}$, Twan van Hooff ${ }^{\mathrm{a}}$, \\ Harry Timmermans ${ }^{\mathrm{d}}$ \\ ${ }^{a}$ Building Physics and Services, Department of the Built Environment, Eindhoven University of Technology, Eindhoven, The Netherlands \\ ${ }^{\mathrm{b}}$ Institute for Hydromechanics, Karlsruhe Institute of Technology KIT, Karlsruhe, Germany \\ ${ }^{\mathrm{c}}$ Building Physics Section, Department of Civil Engineering, Leuven University, Heverlee, Belgium \\ ${ }^{\mathrm{d}}$ Urban Science and Systems, Department of the Built Environment, Eindhoven University of Technology, Eindhoven, The Netherlands
}

\section{A R T I C L E I N F O}

\section{Article history:}

Received 5 February 2014

Received in revised form

23 April 2014

Accepted 25 April 2014

Available online 9 May 2014

\section{Keywords:}

Urban heat island

Climate adaptation

Vegetation

Avenue-trees

Facade greening

Roof greening

\begin{abstract}
A B S T R A C T
The transpirational cooling of vegetation as a measure to mitigate outdoor air temperatures was investigated for a street canyon in the city center of Arnhem, the Netherlands for the meteorological conditions of an afternoon hour on a hot summer day during a heat wave with wind of speed $5.1 \mathrm{~m} \mathrm{~s}^{-1}$ at $10 \mathrm{~m}$ above ground and direction along the canyon. Computational Fluid Dynamics (CFD) simulations with locally applied vegetation in the street, i.e. avenue-trees, facade greening, roof greening and all three combined, were performed. The 3D steady-state Reynolds-averaged Navier-Stokes (RANS) equations were closed by the realizable $\mathrm{k}-\varepsilon$ turbulence model extended with source and sink terms to represent the effects of vegetation on air flow. By specifying a cooling power term in the energy equation, the transpirational cooling by vegetation was accounted for. The strongest cooling by a single vegetative measure was obtained with the avenue-trees with mean and maximum temperature reductions at pedestrian level of $0.43^{\circ} \mathrm{C}$ and $1.6^{\circ} \mathrm{C}$, respectively. Facade greening resulted in rather small changes with mean and maximum reductions of $0.04{ }^{\circ} \mathrm{C}$ and $0.3{ }^{\circ} \mathrm{C}$, respectively. For roof greening no noticeable reductions inside the canyon were found. In the case of a combination of all vegetative measures, cooling in terms of spatial distribution and intensity overall resembled a linear superposition of those of the vegetative measures solely applied with $0.52{ }^{\circ} \mathrm{C}$ mean and $2.0{ }^{\circ} \mathrm{C}$ maximum temperature reduction. Overall, the cooling was restricted to the vicinity of the vegetative measures, i.e. up to a distance of a few meters.
\end{abstract}

(c) 2014 Elsevier Ltd. All rights reserved.

\section{Introduction}

The global mean temperature is estimated to increase by $1.5-$ $4.5^{\circ} \mathrm{C}$ till the year 2100 compared to the mean 1980-2000 temperature and the probability of heat waves is expected to rise, e.g. Ref. [1]. For the Netherlands, climate scenarios of the Royal Netherlands Meteorological Institute (KNMI) indicate a mean temperature increase of $1-5{ }^{\circ} \mathrm{C}$ for summer and of $1.5-3.5{ }^{\circ} \mathrm{C}$ for winter for the same period [1]. Furthermore, in the built environment, in particular in cities, temperatures are generally higher than

\footnotetext{
* Corresponding author. Eindhoven University of Technology, P.O. Box 513, 5600 MB Eindhoven, The Netherlands. Tel.: +31 40247 2195; fax: +31 402438595.

E-mail addresses: c.b.gromke@tue.nl, gromke@kit.edu (C. Gromke).
}

in the surroundings and in rural areas. This phenomenon, called urban heat island effect (UHI), has its origin in the low short-wave reflectivities (albedo values) of city surfaces, the high heat capacity of building materials, the blockage of outgoing long-wave radiation and natural ventilation by the urban geometry as well as in low evaporation rates due to the lack of vegetation, increased air pollution and anthropogenic heat generation in urban environments, e.g. Refs. [2-4]. For example Oke [2] indicates maximum differences in air temperatures between city and countryside of 4$6{ }^{\circ} \mathrm{C}$ at daytime and of $6-10^{\circ} \mathrm{C}$ at nighttime. According to Taha [3], average global urban air temperatures can be $2{ }^{\circ} \mathrm{C}$ higher compared to those in rural areas. Wilby [5] reports a nightly temperature difference of up to $7{ }^{\circ} \mathrm{C}$ between a park in central London and a rural location $32 \mathrm{~km}$ away. For the Dutch city of Rotterdam, Heusinkveld et al. [6] report a difference in air temperature between 
the urban and rural area of $7{ }^{\circ} \mathrm{C}$ during night and $1.2{ }^{\circ} \mathrm{C}$ during day, and Steeneveld et al. [7] show that Dutch cities experience a mean daily maximum UHI of $2.3^{\circ} \mathrm{C}$.

The combination of globally increasing temperatures, the rising probability of heat waves and the urban heat island effect (UHI) causes higher outdoor and indoor temperatures and associated thermal comfort problems, e.g. Ref. [8], an increased building cooling demand and energy consumption, e.g. Ref. [9]. It also implies an amplified risk of heat stress and other health problems among city dwellers, especially the elderly [10]. Heat stress affects people during daily activities and can result in serious health problems and in some cases even in death. During the 2003 heat wave in the Europe, heat stress caused an estimated 1400 to 2200 deaths in the Netherlands [11].

These implications point out the need for measures to reduce high air temperatures in particular during summer heat waves within the urban environment. Possible measures include increasing the short-wave reflectivity (albedo value) of city surfaces, implementing water facilities and implementing vegetation, e.g. Ref. [12]. A way to change the short-wave reflectivity of city surfaces is to paint roof surfaces white. By painting the roof surface of a bungalow house in Sacramento, California white, Akbari et al. [13] changed its short-wave reflectivity from 0.18 to 0.73 and achieved an estimated cooling energy saving of $69 \%$ for the period from June to October 1992. Water facilities decrease air temperatures by evaporative cooling. Examples of water facilities are: mist spray, water ponds, fountains and waterfalls. A study by Nishimura et al. [14] in Osaka, Japan showed that a water pond in a park reduced the air temperatures on its leeward side by $1-2{ }^{\circ} \mathrm{C}$. When waterfalls and fountains were additionally operated, air temperature reductions of up to $4-5{ }^{\circ} \mathrm{C}$ were measured at a distance of around $10 \mathrm{~m}$ at the leeward side of the water pond. Finally, vegetation can be employed to reduce the air temperature. Vegetation provides transpirational cooling and shading, increases the overall shortwave reflectivity of the city, and absorbs and stores less heat than building materials. Examples of vegetation in the urban environment are green roofs and facades or trees in streets or parks. Taha [3] states that soil-vegetation systems can be effective in modifying the near-surface climate by creating oases $2-8{ }^{\circ} \mathrm{C}$ cooler than the surrounding area. In research by Wong et al. [15], the thermal benefits of roof top gardens on the environment were studied in the tropical climate of Singapore. It was measured that the maximum ambient air temperature difference at $0.3 \mathrm{~m}$ above a green versus a bare roof was at maximum $4.2^{\circ} \mathrm{C}$. However, the cooling effect was limited to the close vicinity of the roof greening. At a height of $1.0 \mathrm{~m}$, air temperature differences were reduced to a few tenths of degree Kelvin. The cooling effect of different vegetation arrangements (park and tree row) in a generic building setup was addressed by Dimoudi and Nikolopoulou [16] with Computational Fluid Dynamics (CFD). For a row of trees along a street they obtained a reduction of the air temperature by $1^{\circ} \mathrm{C}$ at pedestrian level (1.5 $\mathrm{m}$ above ground) within the leeward first $10 \mathrm{~m}$. Alexandri and Jones [17] modeled the temperature effects of green walls and green roofs for a generic street canyon located in nine different climates with CFD. Their results show that the hotter and drier a climate is, the stronger the effect of vegetation on mitigating high temperatures is. Furthermore, the study showed that green walls have a stronger effect on the inside canyon temperatures than green roofs. The largest mitigations were found for the combination of both green roofs and walls for which peak decreases in air temperature inside the canyon of $11.3^{\circ} \mathrm{C}$ for the desert climate of Riyadh and of $3.6{ }^{\circ} \mathrm{C}$ for the continental cool summer climate of Moscow were obtained. In a more recent study conducted by Wong et al. [18], a thermal evaluation was made for vertical greenery systems for building facades in the tropical climate of Singapore.
They found reductions in air temperatures of up to $3^{\circ} \mathrm{C} 0.15 \mathrm{~m}$ away from the greening system. Again, a noticeable cooling effect was limited to the close vicinity of the greening $(<1.0 \mathrm{~m})$. Recently, Fröhlich and Matzarakis [19] studied the impact of ground coverage on thermal stress using the microclimate CFD model ENVI-met [20]. An open space in the city of Freiburg in Germany was redesigned from grass to stone covered but with additional water basins. The redesign resulted at $3 \mathrm{~m}$ above ground in increases of the thermal stress expressed in physiological equivalent temperature (PET) by up to $10^{\circ} \mathrm{C}$ over the stone covered surfaces and in reductions of $4-8{ }^{\circ} \mathrm{C}$ over the water basins.

Despite numerous investigations on the effects of vegetative cooling in urban areas, still relevant and challenging questions are unanswered and knowledge gaps exist. Most of the existing modeling studies consider generic urban environments (e.g. Refs. $[16,17,20,21])$. Actual urban environments with their complex geometries are seldom addressed except in a few CFD studies (e.g. Refs. [19,22]). However, in those CFD studies spatially rather limited areas are modeled, i.e. only the site of interest and its immediate surroundings, and hence it may be carefully questioned whether or not the local urban flow field and the advection and turbulent diffusion of heat and vegetative cooling as influenced and formed by the buildings and street canyons in the neighborhood are appropriately simulated.

In this study the transpirational cooling effects of various locally in an urban street canyon applied vegetative measures are investigated. The aim is to assess their effectiveness to mitigate high outdoor air temperatures in heat waves and their potential as urban climate change adaptation measures which become increasingly important with global warming. The reduction of air temperatures is of particular interest as it is one of the most crucial variables which impact outdoor thermal comfort, e.g. expressed as physiological equivalent temperature (PET) or Universal Thermal Climate Index (UTCI), see Refs. [23,24], respectively, and furthermore affects the energy consumption of buildings. Three different types of vegetative measures are studied, namely (i) trees planted along a row in a street, (ii) facade greening, and (iii) green roofs. They are separately and simultaneously applied in a case study for a street, the J.P. van Muijlwijkstraat, in the center of the Dutch city of Arnhem. CFD simulations are performed for the meteorological conditions with clear sky and an easterly wind aligned with the alongcanyon direction on an early afternoon hour ( $15 \mathrm{~h}$ local time) of the 16th July 2003 during a heat wave in Europe. These conditions are selected since it is the warmest time of the day when mitigation measures are most relevant and the easterly wind direction is typically prevailing during summer heat waves in Western Europe. The reason for choosing a hot summer day during the 2003 Western European heat wave is that those temperatures are considered to occur more often in 50-100 years according to climate change scenarios, e.g. Refs. [1,25]. The main distinguishing feature of this study compared to previous ones is the explicit modeling of the building and urban setup surrounding the street canyon of interest to an, to the best of the authors' knowledge, unprecedented extent. The study area comprises the J.P. van Muijlwijkstraat (length $\approx 350 \mathrm{~m}$ ) in its center and resolves the surrounding building and urban geometry up to a distance of approximately $300 \mathrm{~m}$ in high detail. Furthermore, special attention was given to explicitly resolving the existing vegetation and the additional vegetative measures as well as their aerodynamic modeling in terms of mean flow and turbulence and their modeling in terms of transpirational cooling. Based on our validation studies on the effects of vegetation on mean flow and turbulence as well as on transpirational cooling, the high degree in geometry resolution together with the detailed vegetation modeling, the simulations are considered to enable reliable estimates of the flow and 
microclimate and hence the transpirational cooling effect of vegetation in a real complex urban environment. However, the applicability of the outcomes has to be seen in the light of the site, modeling and meteorology specific boundary conditions. The data do not allow conclusions about outdoor thermal comfort since only the effects of vegetation on transpirational cooling and the wind field but not those related to radiation and humidity were considered. Furthermore, although the typical meteorological conditions during heat waves in Western Europe with clear sky and easterly wind were studied, final conclusions about the overall impact of transpirational cooling as a climate change adaptation measure at the specific site would require comprehensive simulations with more variations in the meteorological conditions. The study aims to contribute to the increasing use of CFD in urban physics research to investigate pedestrian wind comfort (e.g. Refs. [26-31]), pollutant dispersion (e.g. Refs. [31-36]), winddriven rain (e.g. Refs. [31,37-41]), natural ventilation (e.g. Refs. [31,42-48]) and thermal urban environment (e.g. Refs. $[28,49,41,50-53])$.

The study is part of the Climate Proof Cities (CPC) project which is part of the Dutch Knowledge for Climate Research Program [54]. Several research organizations and consortia have initiated projects regarding climate change adaptation in cities as the Intergovernmental Panel on Climate Change (IPCC) has expressed the importance of adaptation measures [25]. Climate Proof Cities (CPC) is one of these research consortia investigating the climate vulnerability of urban areas and the development of climate change adaptation measures [55]. The consortium works together with several research institutions, policy makers and city officials to perform an integrated and thorough analysis based on several locations in the Netherlands.

In Section 2 of this paper the numerical setup and validation studies for the aerodynamic effects of vegetation on flow and turbulence as well as for the transpirational cooling by vegetation are detailed. Results of air temperatures for the status quo, i.e. the J.P. van Muijlwijkstraat in its current state, and for 5 different scenarios are presented in Section 3, followed by a discussion in Section 4. Conclusions are drawn and recommendations are provided in Section 5 .
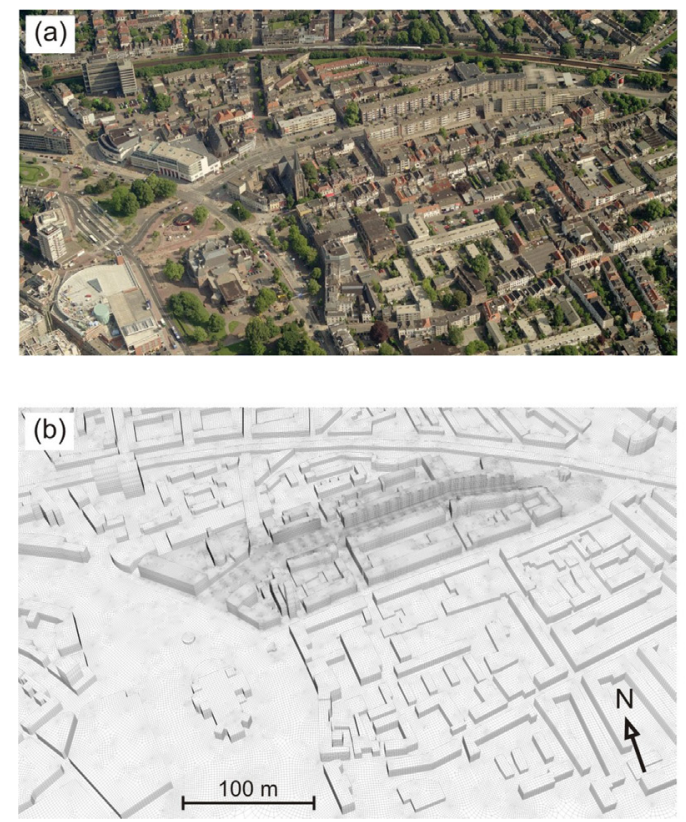

\section{Materials and methods}

\subsection{Computational domain and numerical settings}

The total computational domain has a size of $1200 \mathrm{~m} \times 950 \mathrm{~m} \times 500 \mathrm{~m}(L \times W \times H)$. It comprises an inner area of $900 \mathrm{~m} \times 600 \mathrm{~m}$ in which the building and street geometry is explicitly resolved with the roughly $350 \mathrm{~m}$ long, west-east oriented J.P. van Muijlwijkstraat in its center (Fig. 1). The domain extensions and boundary conditions were chosen in agreement with guidelines for CFD modeling of urban flows [56-59]. The grid was generated using the surface-grid extrusion technique as described in Ref. [60], which was successfully applied in several previous case studies with complex geometries (e.g. Refs. [27,29,35,60-62]). Within the domain, three regions with different grid resolution were generated, namely regions with cells of edge lengths of approximately $0.5 \mathrm{~m}$ for the J.P. van Muijlwijkstraat itself, $1.0 \mathrm{~m}$ for the immediately surrounding building blocks, and $3.0 \mathrm{~m}$ elsewhere (Fig. 1). Transition areas with gradually changing cell sizes were inserted between these regions. The smallest cell size with $0.5 \mathrm{~m}$ edge length ensured that each building and street edge in the center of the domain was resolved by at least 10 cells according to the guidelines. In total, the mesh consisted of 35 million hexahedral cells.

The Computational Fluid Dynamics (CFD) code ANSYS FLUENT 12.4.1 [63] was employed to solve the steady-state Reynolds-averaged Navier-Stokes (RANS) equations with Boussinesq approximation for thermal effects and realizable k- $\varepsilon$ turbulence model closure [64]. The solar ray tracing model and the P1 radiation model were employed to simulate solar irradiation and radiative transfer, e.g. Ref. [65]. Mean flow, turbulence and energy equations were discretized by second order schemes and the SIMPLEC scheme was used for pressure-velocity coupling.

Within the inner area of the computational domain, the aerodynamic roughness length $z_{0}$ was set to 0.03 and $0 \mathrm{~m}$ for the ground and building surfaces, respectively. Outside the inner area, in the approach flow domain where the building and street geometry were not explicitly resolved, the roughness length was set to $z_{0}=0.5 \mathrm{~m}$ to represent the urban and rural fetch according to
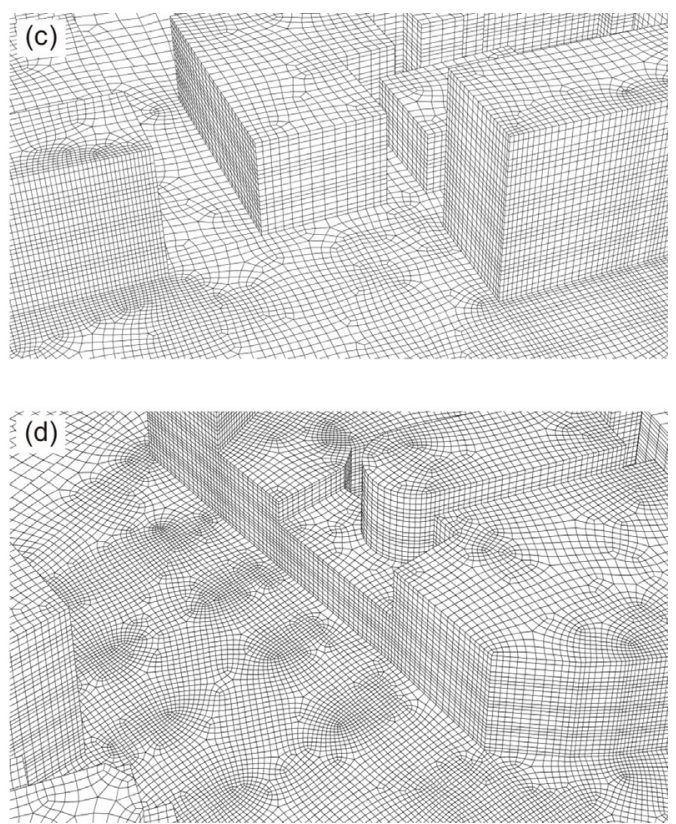

Fig. 1. Aerial view of the J.P. van Muijlwijkstraat (a), computational grid with 35 mio. cells (b) and close-ups of computational grid in the J.P. van Muijlwijkstraat (c, d). 
Wieringa [66] present for the studied east wind direction with $\varphi_{\text {wind }}=90^{\circ}$. Notice that in ANSYS FLUENT the aerodynamic roughness is defined in terms of the equivalent sand grain roughness $k_{\mathrm{s}}$ combined with a roughness constant $C_{\mathrm{s}}$ instead of the roughness length $z_{0}$. The assigned aerodynamic roughness length translates into an equivalent sand grain roughness height by $k_{\mathrm{s}}=9.793 \cdot z_{0} / C_{\mathrm{s}}$ after Blocken et al. $[67,68]$ where $k_{\mathrm{s}}$ has to comply with the requirement of being smaller than half the wall-normal cell size in the wall nearest cells.

At the inflow boundary, vertical profiles for mean velocity $U$ (Eq. (1)), turbulence kinetic energy $k$ (Eq. (2)), and turbulence dissipation rate $\varepsilon$ (Eq. (3)) of the neutrally stratified atmospheric boundary layer were imposed following Richards and Hoxey [69] according to

$U(z)=\frac{u_{*}}{\kappa} \ln \left(\frac{z+z_{0}}{z_{0}}\right)$

$k(z)=\frac{u_{*}^{2}}{\sqrt{C_{\mu}}}$

$\varepsilon(z)=\frac{u_{*}^{3}}{\kappa\left(z+z_{0}\right)}$

with $z$ the vertical position above ground, $z_{0}=0.5 \mathrm{~m}$ the aerodynamic roughness length representative for the terrain windward of the computational domain, $\kappa=0.42$ the van Karman constant, $u^{*}=0.70 \mathrm{~m} \mathrm{~s}^{-1}$ the friction velocity and $C_{\mu}=0.09$. At the ground and building surfaces non-slip boundary conditions together with standard wall functions were applied as described by Launder and Spalding [70] with roughness modification by Cebeci and Bradshaw [71]. A symmetry boundary condition was assigned to the lateral sides and the domain top, and a pressure outlet condition to the outflow boundary.

For the time and day studied, 15:00 h local time of the 16th July 2003, the wind, climate and radiation data were derived from the meteorological station Deelen which is located $5 \mathrm{~km}$ north of the city and $8 \mathrm{~km}$ away from the J.P. van Muijlwijkstraat. The wind was coming from east $\left(\varphi_{\text {wind }}=90^{\circ}\right)$ with $U(z=10 \mathrm{~m})=5.1 \mathrm{~m} \mathrm{~s}^{-1}$ and the air temperature at the inlet was set to $34.5^{\circ} \mathrm{C}$. Incident direct and diffuse solar radiation were set to $750.4 \mathrm{~W} \mathrm{~m}^{-2}$ and $200 \mathrm{~W} \mathrm{~m}^{-2}$, respectively, where the shading of buildings was taken into account but the shading of the vegetative measures was not. To the building walls a thickness $t_{\mathrm{b}}=0.35 \mathrm{~m}$, a specific heat capacity $c_{\mathrm{p}, \mathrm{b}}=900 \mathrm{~J} \mathrm{~kg}^{-1} \mathrm{~K}^{-1}$, a thermal conductivity $\lambda_{\mathrm{b}}=0.8 \mathrm{~W} \mathrm{~m}^{-1} \mathrm{~K}^{-1}$ and a density $\rho_{\mathrm{b}}=2000 \mathrm{~kg} \mathrm{~m}^{-3}$ were assigned. At the outer building walls a short-wave radiative absorption coefficient $a_{\mathrm{b}}=0.8$, an emissivity $\varepsilon_{\mathrm{b}}=0.9$ and at the inner building walls a temperature $T_{\mathrm{b}}=23{ }^{\circ} \mathrm{C}$ were specified. The corresponding values for the ground were $t_{\mathrm{g}}=10 \mathrm{~m}, c_{\mathrm{p}, \mathrm{g}}=300 \mathrm{~J} \mathrm{~kg}^{-1} \mathrm{~K}^{-1}$, $\lambda_{\mathrm{g}}=1.5 \mathrm{~W} \mathrm{~m}^{-1} \mathrm{~K}^{-1}, \rho_{\mathrm{g}}=1600 \mathrm{~kg} \mathrm{~m}^{-3}, a_{\mathrm{g}}=0.85, \varepsilon_{\mathrm{g}}=0.85$ and $T_{\mathrm{g}}=10^{\circ} \mathrm{C}[72-74]$. The convective heat transfer coefficients at the outer building walls and at the upper ground surface were automatically calculated by the CFD code in dependency on local flow properties. The inner building walls and the lower ground surface were adiabatic.

\subsection{Modeling the effects of vegetation on mean air flow and turbulence}

In order to account for the effects of vegetation on air flow, following Green [75], Liu et al. [76] and Sanz [77], terms were added to the transport equations of momentum (Eq. (4)), turbulence kinetic energy (Eq. (5)) and turbulence dissipation rate (Eq. (6)) at computational cells which contain vegetation according to
$S_{u_{i}}=-\rho C_{\mathrm{d}} \mathrm{LAD} U_{i} \mathbf{U}$

$S_{\mathrm{k}}=\rho C_{\mathrm{d}} \operatorname{LAD}\left(\beta_{\mathrm{p}} \mathbf{U}^{3}-\beta_{\mathrm{d}} \mathbf{U} k\right)$

$S_{\varepsilon}=\rho C_{\mathrm{d}} \mathrm{LAD} \frac{\varepsilon}{k}\left(C_{\varepsilon 4} \beta_{\mathrm{p}} \mathbf{U}^{3}-C_{\varepsilon 5} \beta_{\mathrm{d}} \mathbf{U} k\right)$

where $\rho$ is the density of air, $C_{\mathrm{d}}=0.2$ the leaf drag coefficient, LAD is the leaf area density (to be specified later in Section 3 ), $U_{i}$ is the velocity component of direction $i, \mathbf{U}$ the velocity magnitude, $\beta_{\mathrm{p}}=1.0$ the fraction of mean kinetic energy that is converted into wake turbulence kinetic energy $\left(\beta_{\mathrm{p}}=0 \ldots 1\right), \beta_{\mathrm{d}}=5.1$ the coefficient that accounts for short-circuiting of the eddy cascade, $k$ is the turbulence kinetic energy, and $C_{\varepsilon 4}=C_{\varepsilon 5}=0.9$ are empirical coefficients $[77,78]$. Notice that the extra terms in the transport equations of turbulence kinetic energy $k$ and dissipation rate $\varepsilon$ consist of both a source and sink contribution. This is to account for the enhanced production of turbulence, i.e. wake turbulence, which due to its smaller length scales compared to shear turbulence is subjected to faster dissipation so that the vegetation acts as a net sink for turbulence kinetic energy $[75,79,80]$.

\subsection{Modeling the effects of vegetation on transpirational cooling}

In order to account for the effect of vegetation on air temperature, a volumetric cooling power $P_{c}\left[\mathrm{~W} \mathrm{~m}{ }^{-3}\right]$ was attributed per unit volume vegetation as a function of the leaf area density (LAD). This method can be seen as an integral and rather coarse scale approach where the transpirational cooling effect is allocated to a volume containing vegetation, contrary to a microscale approach where the latent heat flux at leaves via stomata is considered, e.g. Refs. [81,82]. The basic principle is that when air flows through vegetation it gets cooled by transpiration mainly from the leaf surfaces. The heat $\mathrm{H}$ required to change the temperature of an object can be calculated according to

$H=c_{\mathrm{p}} m \Delta T$

with $c_{\mathrm{p}}$ the specific heat capacity, $m$ the mass of the object and $\Delta T$ the change in temperature, see e.g. Ref. [83]. Since the volumetric cooling power $P_{\mathrm{c}}$ is understood as the transfer of heat per time $t$ and volume $V\left(P_{\mathrm{c}}=\mathrm{Ht}^{-1} \mathrm{~V}^{-1}=\mathrm{HV}^{-1}\right)$, Eq. (7) can be rearranged to

$\frac{\dot{H}}{V}=P_{\mathrm{c}}=c_{\mathrm{p}} \dot{m} \Delta T \frac{1}{V} \Leftrightarrow \Delta T=P_{\mathrm{c}} V \frac{1}{\dot{m}} \frac{1}{c_{\mathrm{p}}}$

with $\dot{H}$ being the heat transfer rate and $\dot{m}$ the mass flow rate. The right part of Eq. (8) states that the change in temperature $\Delta T$ when air flows through vegetation is proportional to the cooling power $P_{\mathrm{c}}$ and the volume of the vegetation $V$ and inversely proportional to the air mass flow $m$ through the vegetation volume and the specific heat capacity $c_{\mathrm{p}}$ of air. Eq. (8) is based on the simplified assumption that the heat/mass transfer at the leaf surface is not a function of the flow regime and the corresponding heat transfer coefficient.

\subsection{Validation study for the effects of vegetation on mean air flow and turbulence}

For the purpose of validation, measurement data from Amiro [84] of mean flow and turbulence in a $12 \mathrm{~m}$ high black spruce canopy were used. Eqs. (4)-(6) for modeling the effects of vegetation on air flow were implemented as User-Defined-Functions (UDF) in the computational simulations [85]. The computational domain of $100 \mathrm{~m} \times 25 \mathrm{~m} \times 240 \mathrm{~m}(L \times W \times H)$ was equipped with 
coupled periodic boundary conditions at the inflow and outflow side, a no-slip condition with aerodynamic roughness length $z_{0}=0.35 \mathrm{~m}$ (corresponding to a roughness height $k_{\mathrm{s}}=0.49 \mathrm{~m}$ with a roughness constant $C_{s}=7$ ) at the ground, and symmetry boundaries at the lateral sides and top to mimic the homogenous flow in an extended forest (Fig. 2). The flow was driven by a pressure gradient which was automatically taken care of by the CFD code to able a fully-developed flow. The lower $12 \mathrm{~m}$ of the domain were defined as a porous fluid zone representing the black spruce forest to which a vertical leaf area density profile, $\operatorname{LAD}(z)$, according to [84] was attributed. The entire domain was discretized by cubical cells with $1 \mathrm{~m}$ edge length, providing a cell resolution for the
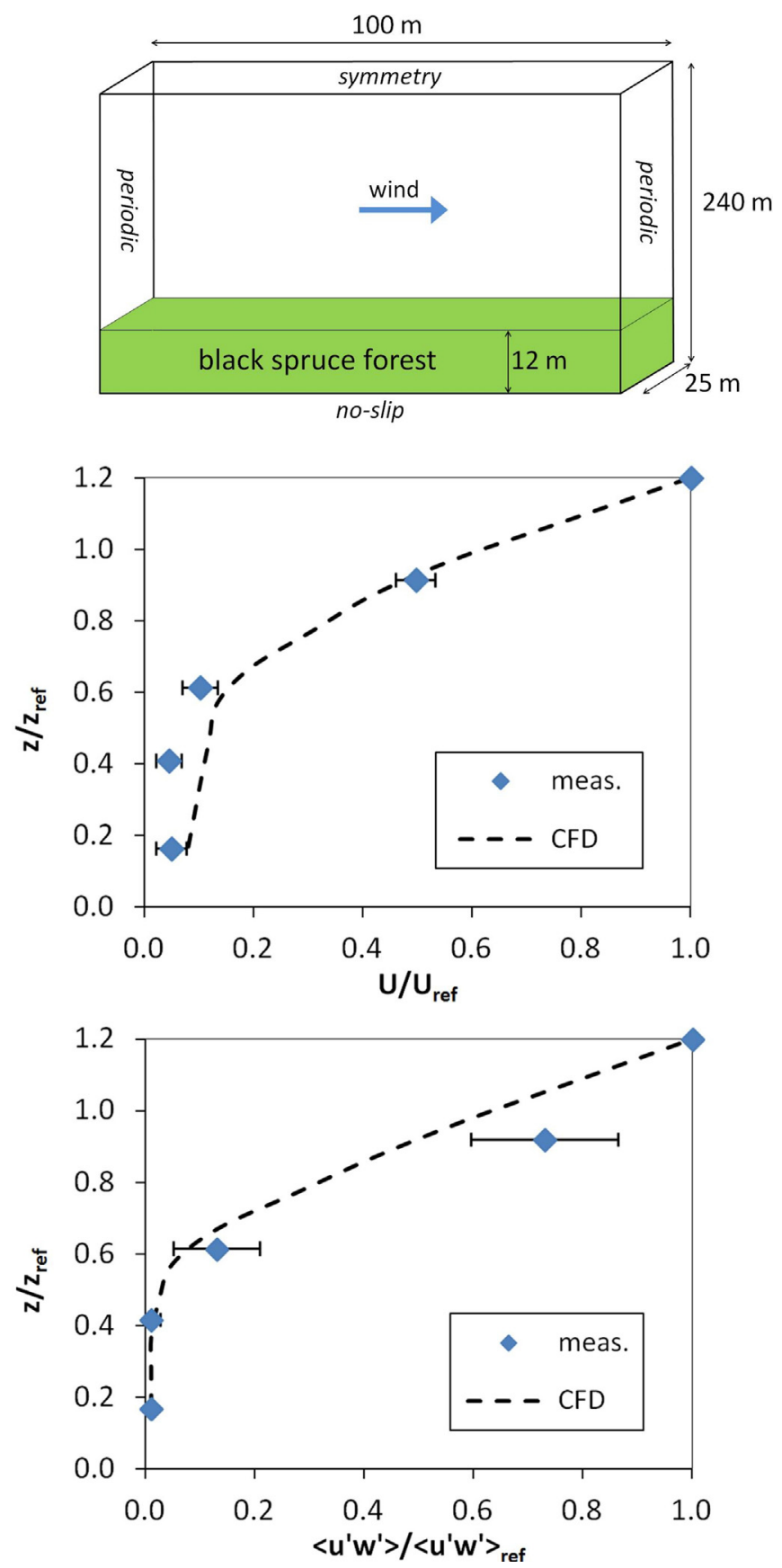

Fig. 2. Computational domain (top) and vertical profiles of normalized mean wind speed (middle) and normalized squared shear stress velocity (bottom). Error bars indicate \pm 1 standard deviation $(\sigma)$. canopy height that is comparable to the cell resolution of the building and street edges around the J.P. van Muijlwijkstraat in the Arnhem case study. An air mass flow rate of $35,000 \mathrm{~kg} \mathrm{~s}^{-1}$ was assigned at the inflow side, resulting in a streamwise wind speed $U=2.6 \mathrm{~m} \mathrm{~s}^{-1}$ at $12 \mathrm{~m}$ height in the fully-developed flow which is in close agreement with [84] where a streamwise wind speed $U=2.5 \mathrm{~m} \mathrm{~s}^{-1}$ at $12 \mathrm{~m}$ height was measured. The same numerical settings regarding the turbulence model and discretizations as in the flow simulations of the Arnhem case study were applied (Section 2.1).

Fig. 2 shows the simulation results together with the measurement data for the mean streamwise velocity $U$ and the square of the shear stress velocity $\left\langle\mathbf{u}^{\prime} \mathbf{w}^{\prime}\right\rangle$. Following [84], the results and data are normalized by the wind speed $U_{\text {ref }}$ and the square of the shear stress velocity $\left\langle\mathrm{u}^{\prime} \mathrm{w}^{\prime}\right\rangle_{\text {ref }}$ at $12 \mathrm{~m}$ height, and the height $z$ above ground by a reference height $z_{\text {ref }}=10 \mathrm{~m}$. In the case of mean streamwise velocity, the maximum relative difference between measurements and simulations is $\sim 40 \%$ and occurs at $z / z_{\text {ref }}=0.4$. However, since the wind speed at this height is very small $\left(\sim 0.1 \mathrm{~m} \mathrm{~s}^{-1}\right)$, the difference in absolute velocities is very small, too. In the upper part of the canopy, a good agreement is found. In the case of the squared shear stress velocity, the maximum relative difference between measurements and simulations in the upper part of the canopy is $\sim 20 \%$. In the lower part of the canopy, a close agreement between both data sets can be seen. Overall, the numerical simulations with the implemented vegetation terms according to Eqs. (4)-(6) are able to model the characteristics of the profiles of mean flow and shear stress velocity within the vegetation canopy and provide a good agreement with the measured data.

\subsection{Determination of the transpirational cooling power of vegetation}

In order to model the effects of vegetation on air temperature by transpirational cooling as described by Eq. (8), the volumetric cooling power of vegetation $P_{\mathrm{c}}$ has to be known. To the best of the authors' knowledge, no direct data about the volumetric cooling power of vegetation are available in literature. Based on a case study, Rahman et al. [86] specified monthly-averaged transpirational energy losses of trees per unit leaf area of 284 and $335 \mathrm{~W} \mathrm{~m}^{-2}$ which correspond to volumetric cooling powers of 284 and $335 \mathrm{~W} \mathrm{~m}^{-3}$, respectively. In order to substantiate these values and to verify the implementation of the volumetric cooling power in the computational simulations, measurement data from a field study of flow and air temperature in courtyards by Shashua-Bar et al. [87,88] were employed. In these studies, the effects of various vegetative measures on the microclimate were investigated for identically constructed, semi-enclosed courtyards (Fig. 3) which differed in the type and arrangement of vegetation. The courtyards are located at the Sde-Boqer campus of the Ben Gurion University in the Negev region in southern Israel.

For the determination of the volumetric cooling power of vegetation $P_{\mathrm{c}}$, steady-state simulations of flow and air temperatures in a courtyard with trees and a bare courtyard were performed and compared with measurement data. Comparisons were performed for three moments in time between noon and early afternoon on the 7th July 2007 for which a meteorological station at $400 \mathrm{~m}$ distance indicated stationary wind and weather conditions. The computational domain with the building arrangement and the courtyard was made to comply with the guidelines formulated in Refs. [56-59]. The courtyard was discretized by cubical cells of $0.15 \mathrm{~m}$ edge length. This resulted in a resolution of 20 cells along the $3 \mathrm{~m}$ high buildings which is comparable to the grid count around the J.P. van Muijlwijkstraat in the Arnhem case study. Outside the building arrangement an unstructured grid with increasing cell 

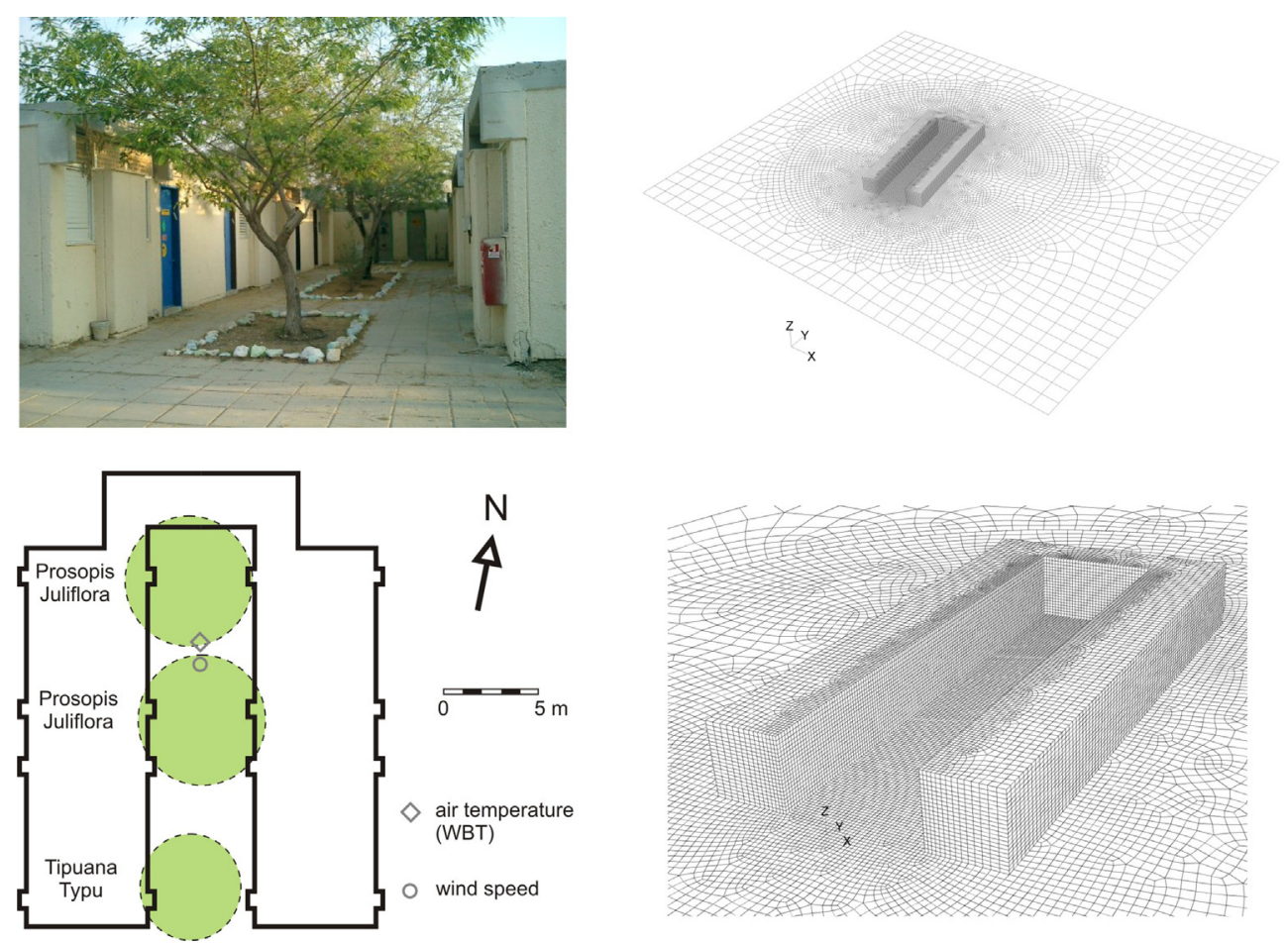

Fig. 3. Courtyard with trees and ground plan of courtyard layout (picture by courtesy of Wolfgang Motzafi-Haller [87,88]) and computational grid.

sizes towards the domain boundaries was constructed. In total, the computational domain was discretized by 670,000 hexahedral cells.

The numerical settings regarding the turbulence and radiation model and discretizations were, unless stated otherwise, the same as for the simulation of the Arnhem case study, see Section 2.1. The meteorological boundary conditions were derived from the reference station located $400 \mathrm{~m}$ away from the courtyard. A roughness length $z_{0}=0.03 \mathrm{~m}$ (corresponding to $k_{\mathrm{s}}=0.042 \mathrm{~m}$ with $C_{\mathrm{s}}=7$ ) was assigned to the ground and building walls. Thermal and radiative properties of the building materials and surfaces were specified as provided by one of the authors of $[87,88]$ (personal communication with Evyatar Erell). The aerodynamic effects of the trees inside the courtyard were modeled by the vegetation terms given in Eqs. (4)(6) with a leaf area density $\operatorname{LAD}=2.0 \mathrm{~m}^{2} \mathrm{~m}^{-3}$. Furthermore, a volumetric cooling power was assigned to the cells containing vegetation to model the effect of the trees on air temperature. The approach to determine the volumetric cooling power $P_{\mathrm{c}}$ was to iteratively change its value until agreement in the air temperature inside the courtyard between the measurement and simulation was achieved. Since the foliage is rather sparse and permeable to light (Fig. 3), the effect of shading by the tree crowns on the air temperature at the measurement position at $1.5 \mathrm{~m}$ above ground inside the courtyard was assumed to be negligible and not accounted for in the simulations. This assumption is substantiated by temperature recordings obtained within the same measurement campaign but for a neighboring courtyard spanned by a fabric shading mesh mounted at roof top height for which no reduction in air temperature in comparison to the bare courtyard was found $[87,88]$.

Fig. 4 shows the measured and simulated air temperatures at $1.5 \mathrm{~m}$ height below the northernmost tree (Fig. 3) in the bare courtyard and the courtyard with trees. For the bare courtyard, slight deviations between the simulated and measured data for two out of three moments in time are found with an average deviation of $0.4{ }^{\circ} \mathrm{C}$. For the courtyard with trees, simulations with 3 different volumetric cooling powers were performed, namely $P_{\mathrm{c}}=250,500$ and $750 \mathrm{~W} \mathrm{~m}^{-3}$. The obtained air temperature decreases fairly linearly with increasing volumetric cooling power. The average

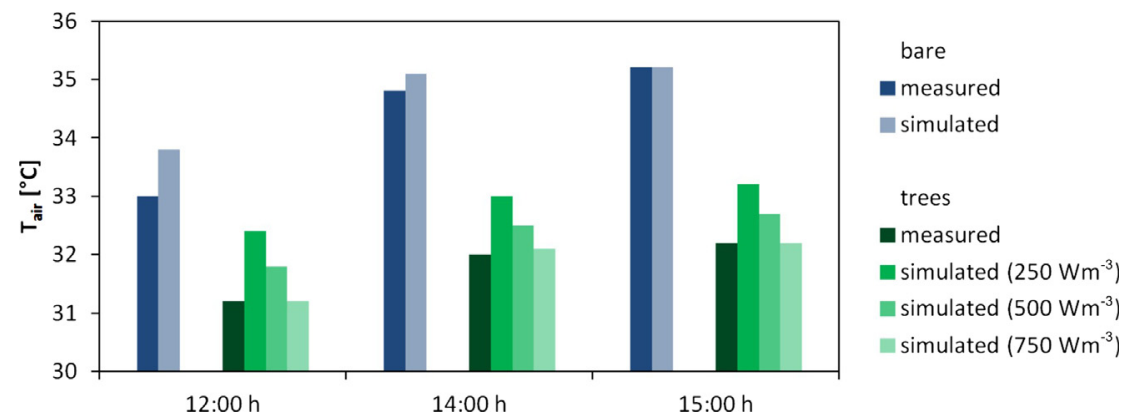

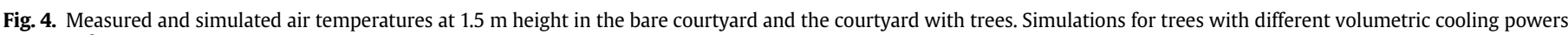
$P_{\mathrm{c}}\left[\mathrm{W} \mathrm{m} \mathrm{m}^{-3}\right]$. 


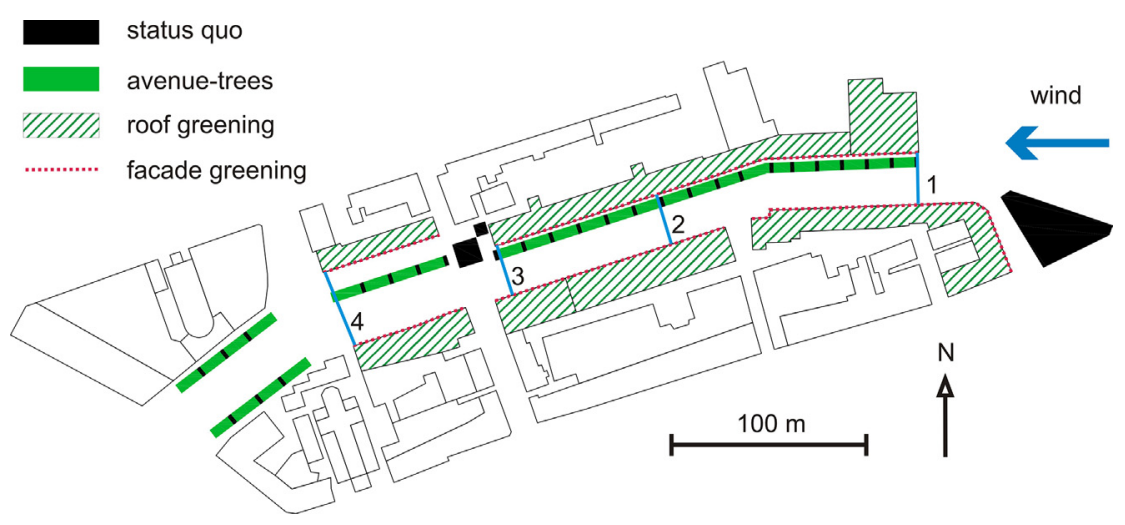

Fig. 5. Ground plan of J.P. van Muijlwijkstraat with status quo and scenarios.

deviations between the simulations and the measurements are 1.1, 0.5 and $0.0{ }^{\circ} \mathrm{C}$, respectively. Based on the fact that for the bare courtyard an average deviation of $0.4{ }^{\circ} \mathrm{C}$ was found, the volumetric cooling power of the courtyard trees with $\mathrm{LAD}=2.0 \mathrm{~m}^{2} \mathrm{~m}^{-3}$ is estimated to $P_{\mathrm{c}}=500 \mathrm{~W} \mathrm{~m}^{-3}$ which translates into a volumetric cooling power $P_{\mathrm{c}}=250 \mathrm{~W} \mathrm{~m}^{-3}$ for a leaf area density of unity $\left(\mathrm{LAD}=1 \mathrm{~m}^{2} \mathrm{~m}^{-3}\right)$.

The herein estimated volumetric cooling power compares well with data of Rahman et al. [86] which report volumetric cooling powers of 284 and $335 \mathrm{~W} \mathrm{~m}^{-3}$ per unity of leaf area density for deciduous trees in Manchester/UK during summer. Finally, it is important to mention that the trees in the courtyard were daily irrigated. The transpiration from the leaf surfaces was thus not restricted by limited water supply. Cooling effects of trees which suffer from limited water supply are lower and considerably reduced in the case of water stress (e.g. Ref. [86]).

\section{Results}

The status quo with the existing trees in the J.P. van Muijlwijkstraat (reference case) and five scenarios with various vegetative measures applied either in the street canyon or at the walls or roofs of the immediate surrounding buildings were studied (Fig. 5). In particular, the following cases were studied:

- Status quo: Few, rather small deciduous trees within the street canyon and a patch of deciduous trees $\left(\sim 600 \mathrm{~m}^{2}\right)$ directly eastward of the J.P. van Muijlwijkstraat (Section 3.1)

- Scenario 1: No-vegetation (Section 3.2)

- Scenario 2: Avenue-tree row in the street canyon and trees from status quo (Section 3.3)

- Scenario 3: Facade greening and trees from status quo (Section 3.4)

- Scenario 4: Roof greening and trees from status quo (Section 3.5)

- Scenario 5: Avenue-tree row, facade greening, roof greening and trees from status quo (Section 3.6)

Fig. 5 shows next to the status quo and the scenarios, the positions of several vertical cross sections $(1,2,3,4)$ within the street canyon. For these cross sections, analyses of the effects of vegetation measures on air temperature and comparisons between scenarios will be provided. The status quo, i.e. the existing situation with a triangular shaped patch $\left(\sim 600 \mathrm{~m}^{2}\right)$ consisting of roughly 20 trees directly eastward of the J.P. van Muijlwijkstraat and few rather small trees within the street canyon will serve as reference case. The status quo and the scenarios were simulated for the 16th July 2003, 15:00 h local time, when the wind was coming from east $\left(\varphi_{\text {wind }}=90^{\circ}\right)$ with a reference wind speed at $10 \mathrm{~m}$ height of $U(z=10 \mathrm{~m})=5.1 \mathrm{~m} \mathrm{~s}^{-1}$ and the air temperature of the approach flow was $34.5^{\circ} \mathrm{C}$.

\subsection{Status quo}

In this case, a few deciduous trees spaced approximately $15 \mathrm{~m}$ apart from each other at the northern side of the J.P. van Muijlwijkstraat (Fig. 6) and a triangular shaped patch with roughly 20 trees located eastward in front of the street canyon are present. For the simulations, the leaf area density of the trees was set to $\mathrm{LAD}=0.55 \mathrm{~m}^{2} \mathrm{~m}^{-3}$ and the volumetric cooling power to $137.5 \mathrm{~W} \mathrm{~m}^{-3}$, accordingly.

Fig. 7 shows air temperatures at $2 \mathrm{~m}$ height above ground. In general, air temperatures between 35 and $37^{\circ} \mathrm{C}$ are found in the J.P. van Muijlwijkstraat with some spots of higher temperatures close to the building walls. The simulated average temperature at $2 \mathrm{~m}$ height is $36.11^{\circ} \mathrm{C}$. The transpirational cooling effect of the upstream patch of trees is noticeable inside the canopy itself and in the eastern part of the street canyon. Within the canopy, air temperatures are largely around $1{ }^{\circ} \mathrm{C}$ cooler than windward from it. This

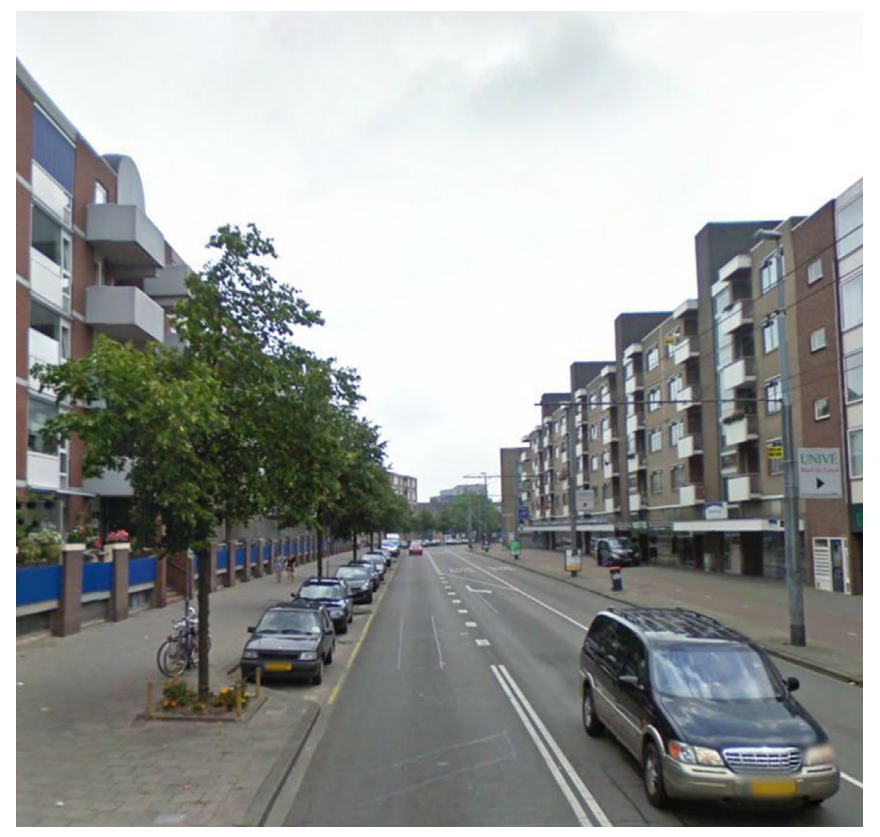

Fig. 6. Existing trees on the north side of J.P. van Muijlwijkstraat (view from west). 


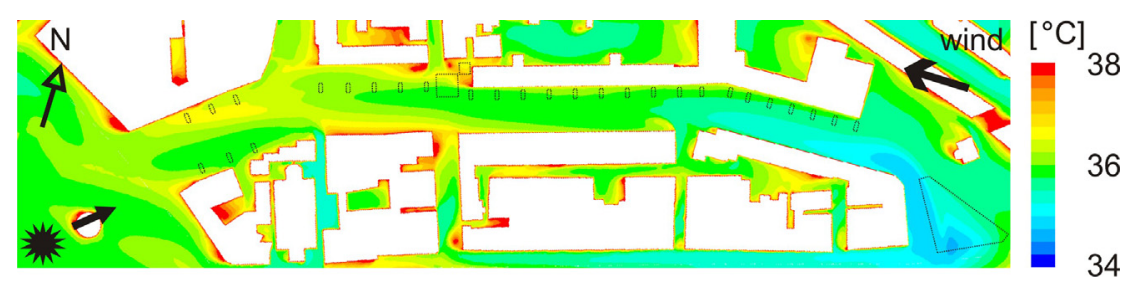

Fig. 7. Air temperatures $\left[{ }^{\circ} \mathrm{C}\right]$ at $2 \mathrm{~m}$ above ground for the status quo. Dotted lines indicate the locations of the trees.

cooler air is partly advected into the J.P. van Muijlwijkstraat and into the street south of it where continuous increases in air temperature along the mean wind direction are found. A pronounced effect of the trees inside the street canyon on the air temperature in the form of cooler spots can not be identified.

Fig. 8 shows the air temperatures in the 4 vertical cross sections as indicated in Fig. 5. In general, the air temperatures in the cross sections are between 35 and $37^{\circ} \mathrm{C}$ with higher temperatures in the bottom part of the street canyon. Slightly lower air temperatures occur always at the north side of the street except for cross section 1. The lower temperatures at the north side are attributed to the presence of trees within the canyon. The lower temperatures at the south side in cross section 1 are attributed to the cooler air originating from the eastward located patch of trees which enters the J.P. van Muijlwijkstraat mainly close the south buildings. Tendentially, the air temperature shows a slight increase along the street canyon in the approach flow wind direction with average values of $35.14,35.51,35.57$ and $35.91{ }^{\circ} \mathrm{C}$ in the first to fourth cross section, respectively.

\subsection{Scenario 1: no-vegetation}

For this scenario, the trees inside the J.P. van Muijlwijkstraat and the eastward located patch of trees were removed. The purpose of this scenario is to figure out whether or not the existing trees already provide a noticeable transpirational cooling of the air temperature within the street canyon.

The air temperatures at $2 \mathrm{~m}$ above ground are shown in Fig. 9. On average, the air temperature over the entire length and width of the street canyon at $2 \mathrm{~m}$ is $36.28{ }^{\circ} \mathrm{C}$ compared to $36.11{ }^{\circ} \mathrm{C}$ in the status quo (Fig. 7). This marginal difference indicates that the existing trees are not able to provide a significant transpirational cooling for the entire street canyon. The implications of the eastward patch of trees are restricted to the position of the patch itself where differences in air temperature of approximately $1^{\circ} \mathrm{C}$ can be observed and to the eastern part of the J.P. van Muijlwijkstraat.

The contour plots in Fig. 10 show the differences in air temperature of the no-vegetation scenario relative to the status quo for the vertical cross sections 1 and 2 as indicated in Fig. 5. In cross section 1, an increase in air temperature at the south side of the street canyon is apparent with the largest temperature differences of $0.5{ }^{\circ} \mathrm{C}$ close to the ground. This increase is attributed to the missing advection of cooler air originating from the patch of trees eastward of the J.P. van Muijlwijkstraat as can be seen by comparison of Fig. 9 with Fig. 7. The air temperature at the north side of the street remains unaffected since the cooler air enters the canyon predominantly on its south side. On average, the temperature increase in cross section 1 is $0.16^{\circ} \mathrm{C}$. On the contrary, the temperature differences in cross section 2 are most prominent at the north side of the canyon (average increase $0.11^{\circ} \mathrm{C}$ ). The air flow does not

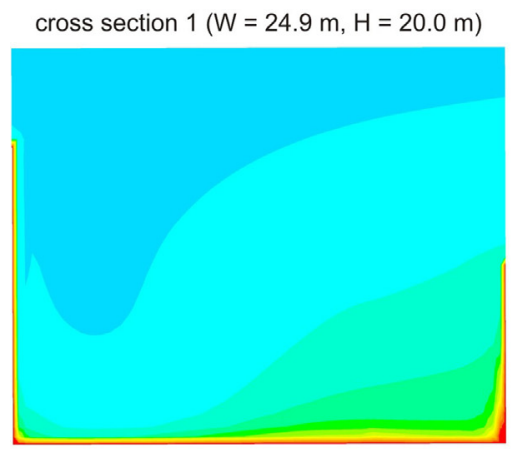

cross section $2(\mathrm{~W}=24.8 \mathrm{~m}, \mathrm{H}=20.0 \mathrm{~m})$
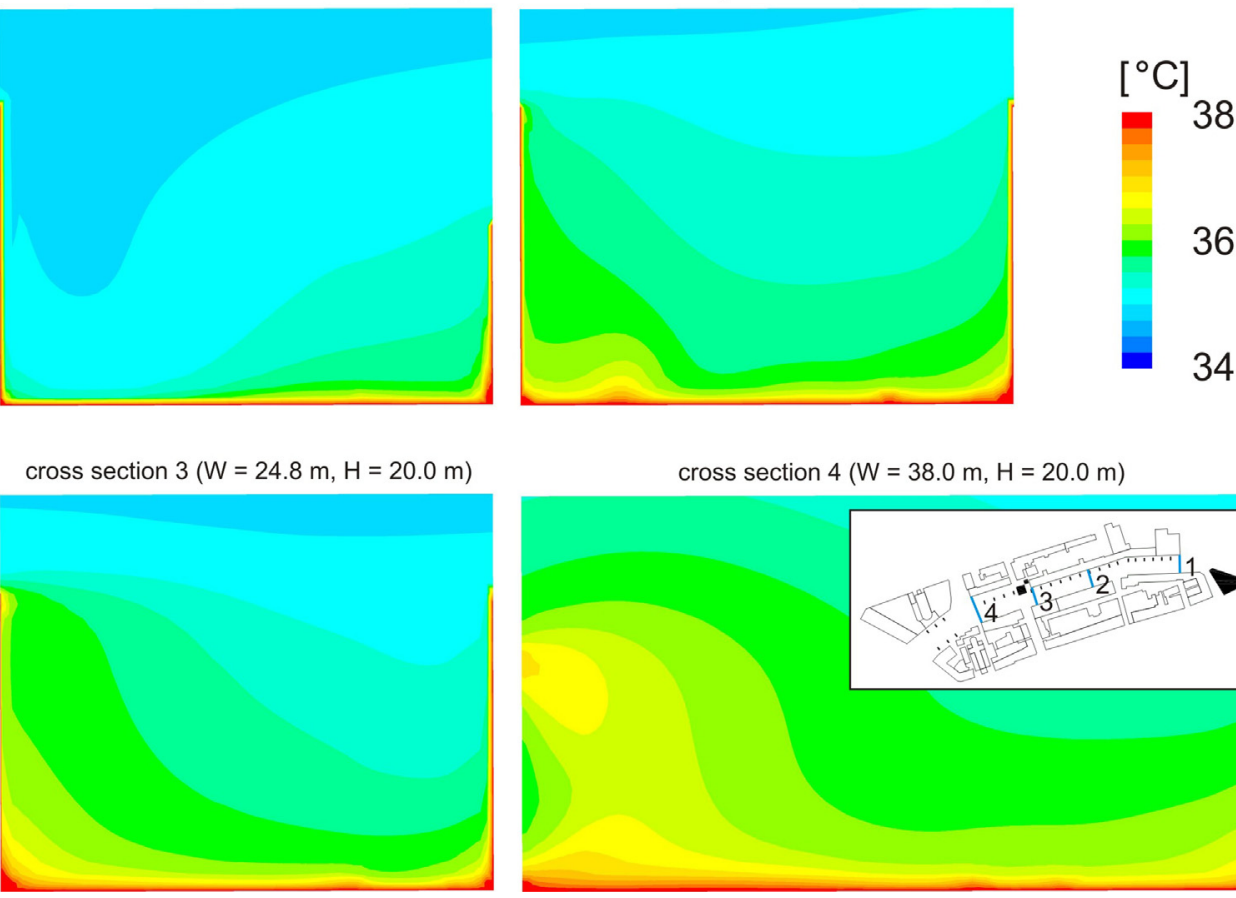

Fig. 8. Air temperatures $\left[{ }^{\circ} \mathrm{C}\right]$ for the status quo in the vertical cross sections (1-4) as also indicated in Fig. 5 . View from east to west. 


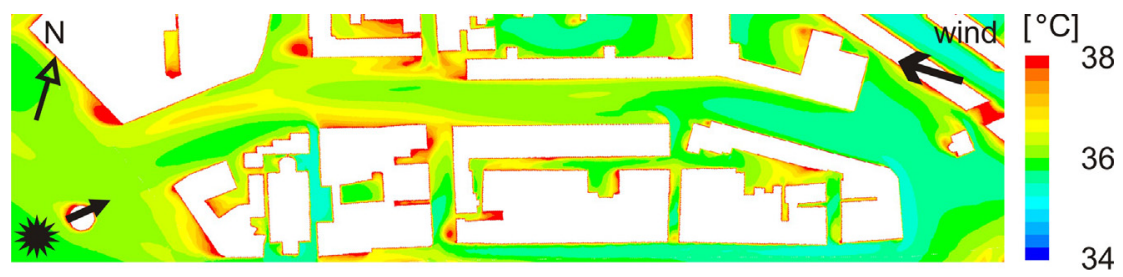

Fig. 9. Air temperatures $\left[{ }^{\circ} \mathrm{C}\right]$ at $2 \mathrm{~m}$ above ground for the no-vegetation scenario.
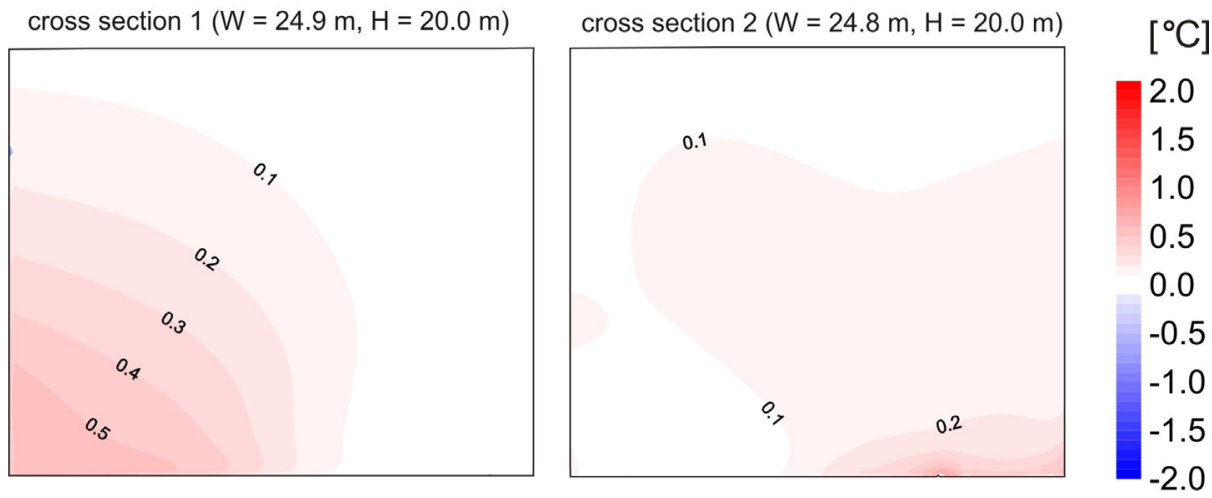

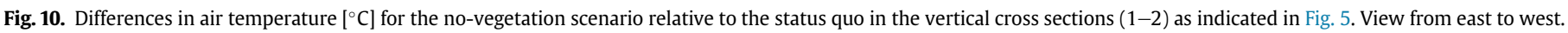

follow the kink in the J.P. van Muijlwijkstraat after the first building block on the south side but streams towards the north side of the street canyon. Furthermore, the absence of trees inside the canyon also contributes to the small temperature increase on the north side. In cross section 3 and 4 only slightly increased air temperatures are found in the lower parts of the street canyon (not shown here). The noticeably affected cross section areas are also smaller than those of cross section 1 and 2.

\subsection{Scenario 2: avenue-tree row}

This scenario comprises next to the existing vegetation from the status quo additional trees inside the street canyon as shown in Fig. 5. The new trees are arranged in line with the existing trees and form a gapless row of avenue-trees with a crown of $5 \mathrm{~m}$ width and $6 \mathrm{~m}$ height starting at $4 \mathrm{~m}$ above ground. The leaf area density of the trees was set to $\mathrm{LAD}=0.55 \mathrm{~m}^{2} \mathrm{~m}^{-3}$ representing a typical LAD value of common urban deciduous trees [89] and the volumetric cooling power was accordingly set to $137.5 \mathrm{~W} \mathrm{~m}^{-3}$.

Fig. 11 shows the air temperatures at $2 \mathrm{~m}$ above ground. By comparison with the status quo (Fig. 7), a noticeable transpirational cooling effect due to the additional trees becomes apparent. The cooling by the avenue-trees affects almost the entire pedestrian level of the street canyon where large parts show an air temperature reduction of $1{ }^{\circ} \mathrm{C}$ or more compared to the status quo. In particular at the north side in the central part of the J.P. van Muijlwijkstraat, pronounced temperature decreases of $2{ }^{\circ} \mathrm{C}$ are present. The average decrease in air temperature over the entire street canyon length and width at $2 \mathrm{~m}$ height is $0.43{ }^{\circ} \mathrm{C}$ in comparison to the status quo.

The differences in air temperatures between this scenario and the status quo are provided in Fig. 12. The position of the avenuetree row is indicated by the dashed square. In cross section 1 , at the inflow side of the street canyon, the inward advected air is still not affected by the trees and their transpirational cooling and no differences in temperature are noticed. In cross section 2, the cooling effect of the trees is clearly visible. Decreased air temperatures are present in the vicinity of the avenue-tree row. However, the cooling is limited to around one third of the cross section area with an average temperature decrease of $0.20^{\circ} \mathrm{C}$ over the entire cross section. The maximum transpirational cooling of $1.6{ }^{\circ} \mathrm{C}$ is found inside the tree crowns or in the gap between the tree row and building wall. The temperature gradients suggest a flow with a component towards the building walls through the trees by which the air gets subsequently cooled, resulting in cooler air within the gap. In cross section 3 and 4, the air over the entire street canyon width is affected by the transpirational cooling of the trees with lower temperatures at pedestrian level. The strongest decreases in temperatures occur inside the avenue-trees with a maximum reduction of $1.6{ }^{\circ} \mathrm{C}$ in cross section 3 and 4 . In comparison to the status quo, average temperature reductions of 0.46 and $0.42{ }^{\circ} \mathrm{C}$ are obtained for those cross sections. The air temperature reductions obtained here are in general agreement with the results of Dimoudi and Nikolopoulou [16] who report a temperature decrease of $1{ }^{\circ} \mathrm{C}$ for a street with a row of trees, noticeable within the first $10 \mathrm{~m}$ leeward of the trees.

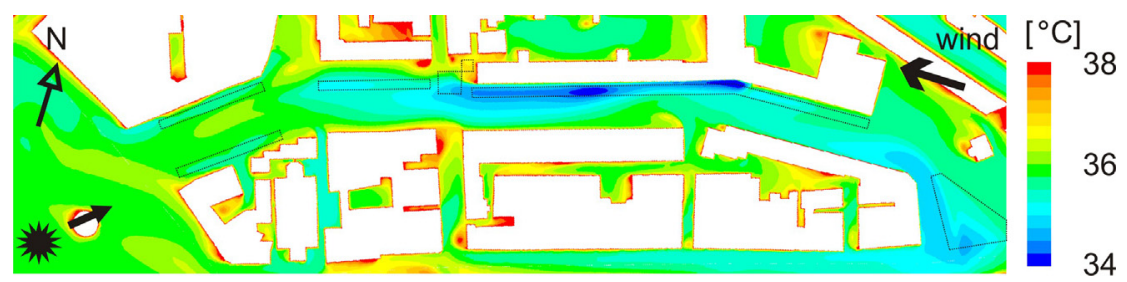

Fig. 11. Air temperatures $\left[{ }^{\circ} \mathrm{C}\right]$ at $2 \mathrm{~m}$ above ground for the avenue-tree row scenario. Dotted lines indicate the locations of the trees. 

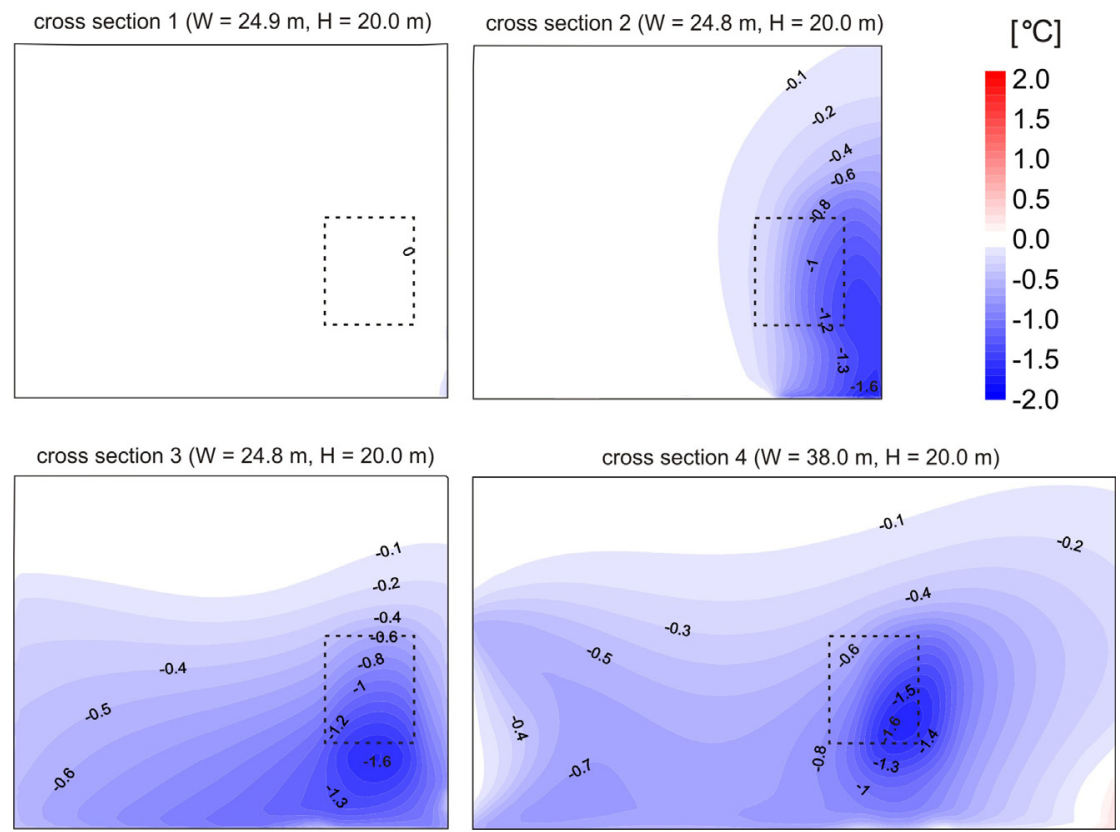

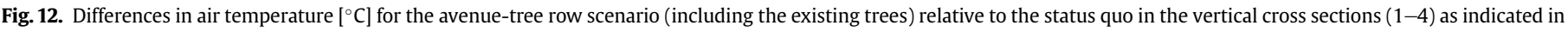
Fig. 5. View from east to west. Dashed boxes show the location of the avenue-trees row.

\subsection{Scenario 3: facade greening}

Facade greening was applied to the building walls facing the J.P. van Muijlwijkstraat additionally to the existing trees (Fig. 5). To this end, a vegetation zone was defined in the computational domain in all cells next to the building facades along the entire street canyon. Typical leaf area indices (LAI) of facade greening (e.g. ivy) are between 0.25 and $1.5 \mathrm{~m}^{2} \mathrm{~m}^{-2}$, e.g. Ref. [90]. However, since due to glazing, balconies, openings and doors (Fig. 6) only parts of the facades are available for greening, facade-averaged leaf area indices are lower. Assuming a coverage fraction of $50 \%$ yields facadeaveraged leaf area indices LAI between 0.125 and $0.75 \mathrm{~m}^{2} \mathrm{~m}^{-2}$. For the simulation, the leaf area density of the facade greening was set to LAD $=0.75 \mathrm{~m}^{2} \mathrm{~m}^{-3}$ which translates into a leaf area index of $\mathrm{LAI}=0.375 \mathrm{~m}^{2} \mathrm{~m}^{-2}$ for the given wall-normal length of $0.5 \mathrm{~m}$ of the facade adjacent cells $(\mathrm{LAI}=\mathrm{LAD} \cdot \Delta l)$. The corresponding volumetric cooling power assigned to the facade greening was $P_{\mathrm{c}}=187.5 \mathrm{~W} \mathrm{~m}^{-3}$.

The simulations revealed that the transpirational cooling effect of the facade greening on air temperatures in the street canyon was confined to the near vicinity up to a few meter away from the building walls. This was also observed in a study of vertical greening systems by Wong et al. [18]. As can be seen for the cross sections 2 and 3 in Fig. 13, a stronger cooling effect is present at the south side of the J. P van Muijlwijkstraat. Directly adjacent to the facade greening in thin stripes maximum reductions in air temperature of $0.5^{\circ} \mathrm{C}$ relative to the status quo are visible. The average decreases in air temperature are 0.07 and $0.10{ }^{\circ} \mathrm{C}$ in cross section 2 and 3 , respectively. Very limited changes in comparison with the status quo were found at $2 \mathrm{~m}$ above ground (not shown here). The average air temperature for the facade scenario at that height is $36.07{ }^{\circ} \mathrm{C}$ and only marginally lower than in the status quo $\left(36.11^{\circ} \mathrm{C}\right)$.

\subsection{Scenario 4: roof greening}

Greening was applied on top of the building blocks on the south and north side of the J.P. van Muijlwijkstraat (Fig. 5) in addition to the existing trees. In the computational domain, vegetation zones were assigned to the roof adjacent cells of $0.5 \mathrm{~m}$ height to which a leaf area density of $\mathrm{LAD}=1.5 \mathrm{~m}^{2} \mathrm{~m}^{-3}$ (with $\mathrm{LAI}=\mathrm{LAD} \cdot \Delta l$ corresponding to a leaf area index $\mathrm{LAI}=0.75 \mathrm{~m}^{2} \mathrm{~m}^{-2}$ ) and a volumetric cooling power of $P_{\mathrm{c}}=375 \mathrm{~W} \mathrm{~m}^{-3}$ were attributed. Typical leaf area indices (LAI) of roof greening vary between 2 and $5 \mathrm{~m}^{2} \mathrm{~m}^{-2}$, e.g. Ref.

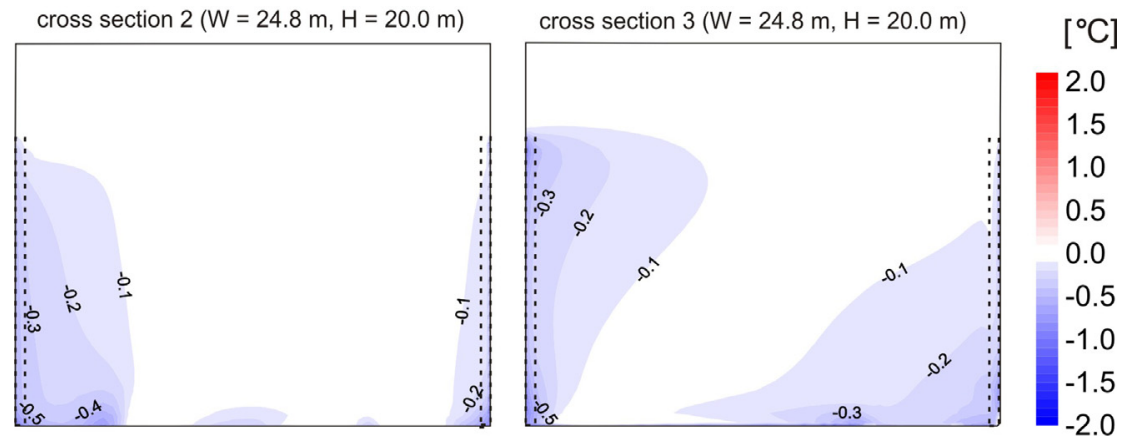

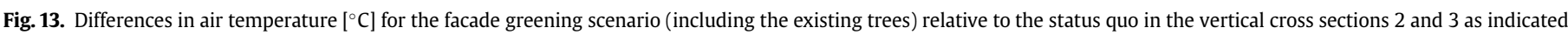
in Fig. 5. View from east to west. Dashed lines show the location of the facade greening. 


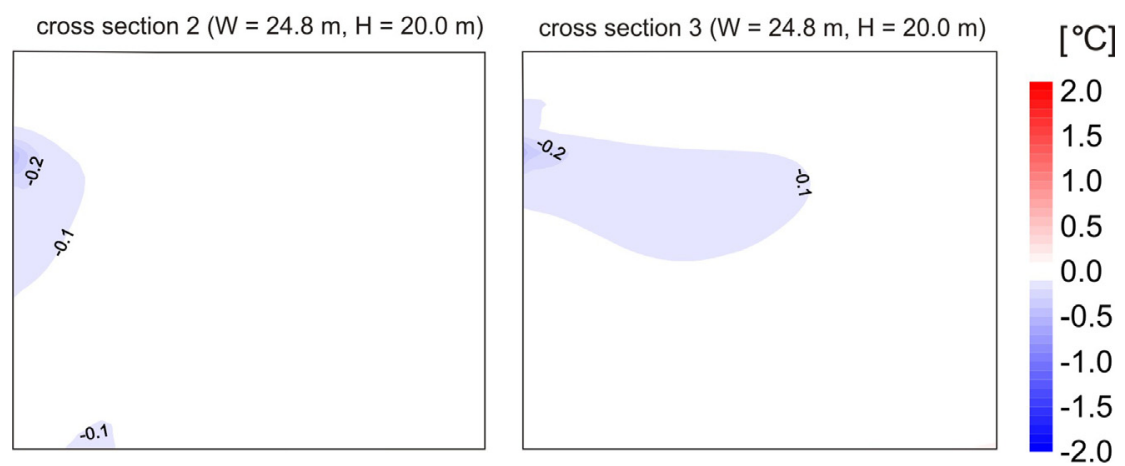

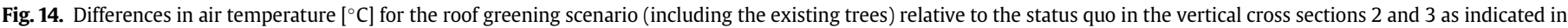
Fig. 5. View from east to west.

[91]. However, since due to installations like antennas, photovoltaic cells or for exterior cleaning including access paths and due to inclined roofs or roof windows only fractions of the roofs are available for greening, roof-averaged leaf area indices are lower. Assuming a coverage fraction of $25 \%$ yields roof-averaged leaf area indices LAI between 0.5 and $2.5 \mathrm{~m}^{2} \mathrm{~m}^{-2}$.

Compared to the status quo, only marginal effects of the roof greening on the air temperatures inside the street canyon were found. Fig. 14 shows that in the cross sections 2 and 3 very small temperature decreases in the upper part of the canyon were achieved. In the cross section 1 and 4 even fewer changes are to observe (not shown here). Overall, no noticeable changes can be identified at $2 \mathrm{~m}$ height (not shown here). The cooling in the street canyon is clearly smaller than that of facade greening which is corroborated by Alexandri and Jones [17] who also report a weaker cooling effect of roof greening in comparison to facade greening. Apparently, for the present mean wind direction, the air cooled by the roof greening is basically advected parallel to the street direction over the building roofs and only small amounts of it penetrate into the street canyon. Wong et al. [15] also observed that the cooling effect of roof top gardens is limited to the close vicinity of the roof level.

\subsection{Scenario 5: avenue-tree row, facade greening and roof greening}

The final scenario comprises all vegetative measures simultaneously applied in addition to the existing trees. The characteristics of each vegetative measure, i.e. leaf area density (LAD) and cooling power $\left(P_{\mathrm{c}}\right)$, are the same as specified before. This scenario was studied in order to assess whether the resulting transpirational cooling by all vegetative measures corresponds to or resembles a simple linear superposition of each measure exclusively applied, or if this is not the case due to intricate interactions and modifications in the mean flow and turbulence field.

Fig. 15 shows the differences in air temperature between the scenario of all vegetative measures and the status quo for cross section 2 and 3 . The general pattern of temperature reductions is dominated by the avenue-tree row on the north side of the street canyon and by the facade greening applied at the walls of the southern buildings. Maximum reductions in air temperatures of $2.0{ }^{\circ} \mathrm{C}$ and $1.8{ }^{\circ} \mathrm{C}$ and average reductions of 0.31 and $0.65{ }^{\circ} \mathrm{C}$ were achieved in cross section 2 and 3, respectively. At $2 \mathrm{~m}$ height in the street canyon, an average air temperature of $35.59{ }^{\circ} \mathrm{C}$ instead of $36.11{ }^{\circ} \mathrm{C}$ in the status quo was obtained with a temperature field (not shown here) resembling that of the avenue-tree row scenario (Fig. 11). Hence, the combination of all vegetative measures resulted in the strongest transpirational cooling of air temperatures within the J.P. van Muijlwijkstraat. Alexandri and Jones [17], who studied the effects of facade and roof greening on air temperatures in urban street canyons also found the strongest cooling effect for the case of both measures simultaneously applied.

\section{Discussion}

\subsection{Comparison of the transpirational cooling effectiveness of vegetative measures}

The results from the five scenarios and the status quo showed that the employed vegetative measures have different effects on the air temperatures in the J.P. van Muijlwijkstraat. It could be shown that already for the status quo the rather sparse existing trees inside the canyon and eastward of it provide some cooling inside the street canyon. In particular the eastward located patch of trees led to marked and widespread temperature decreases in the
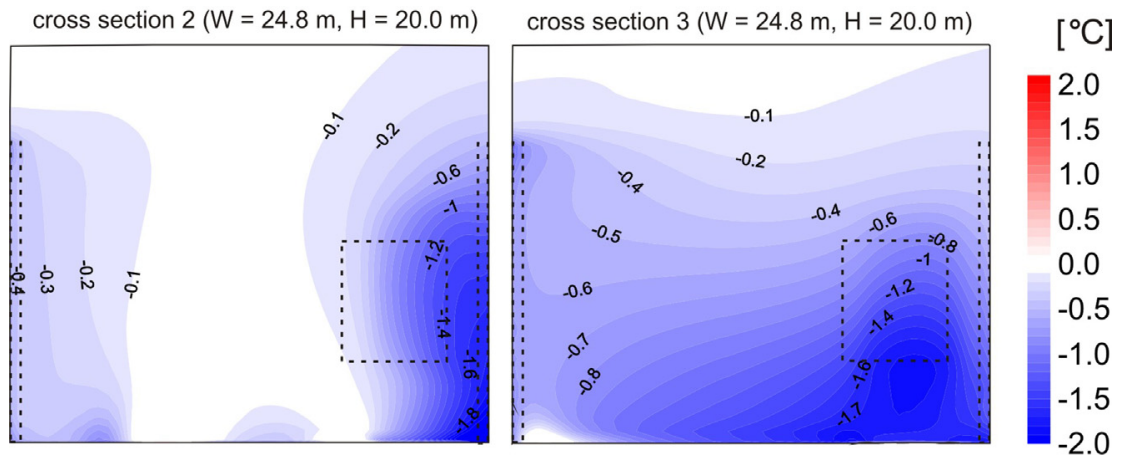

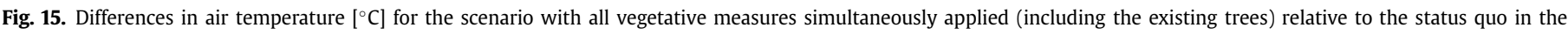
vertical cross sections 2 and 3 as indicated in Fig. 5. View from east to west. 
Table 1

Mean and maximum differences in air temperature compared to the status quo in the 4 vertical cross sections and at $2 \mathrm{~m}$ height.

\begin{tabular}{|c|c|c|c|}
\hline & $\begin{array}{l}\text { Cross section } 1-4 \\
\Delta T_{\text {mean }}\left[{ }^{\circ} \mathrm{C}\right]\end{array}$ & $\begin{array}{l}\text { Cross section } 1-4 \\
\Delta T_{\max }\left[{ }^{\circ} \mathrm{C}\right]\end{array}$ & $\begin{array}{l}\text { Pedestrian level }(2 \mathrm{~m}) \\
\Delta T_{\text {mean }}\left[{ }^{\circ} \mathrm{C}\right]\end{array}$ \\
\hline No-vegetation & +0.09 & +0.60 & +0.17 \\
\hline Avenue-tree row & -0.29 & -1.60 & -0.43 \\
\hline Facade greening & -0.06 & -0.50 & -0.04 \\
\hline Roof greening & -0.05 & -0.20 & -0.03 \\
\hline $\begin{array}{l}\text { All vegetative } \\
\text { measures }\end{array}$ & -0.39 & -2.00 & -0.52 \\
\hline
\end{tabular}

east part of the canyon. However, their influence further downstream in the street canyon diminished and the effect of the isolated trees along the street was too small to provide a significant cooling. The biggest cooling effect was found for the avenue-tree row scenario which in comparison to the status quo provided for extended parts at pedestrian level an air temperature reduction of more than $1.0^{\circ} \mathrm{C}$ and an average reduction of $0.43^{\circ} \mathrm{C}$. Whereas on the very eastward side where the air streams into the street canyon virtually no effect could be identified, the cooling became increasingly stronger both in magnitude and spatial extension along the mean wind direction from east to west, i.e. the air was subsequently cooled down on its pathway through the tree crowns. The facade greening basically provided lower air temperatures in the vicinity of the building walls noticeable within a distance of a few meter $(<5 \mathrm{~m})$ away from the walls. Here, local decreases in temperature of maximum $0.5{ }^{\circ} \mathrm{C}$ where were observed. The effect on the south side of the street canyon was more pronounced than on the north side. However, the overall transpirational cooling due to facade greening in the J.P. van Muijlwijkstraat was rather small. For the roof greening almost no air temperature reductions were found in the street canyon. Only marginal decreases at the roof level were observed, but no transpirational cooling effect was noticed for the pedestrian level. The strongest transpirational cooling effect was obtained if all vegetative measures were simultaneously applied. A comparison of the contour plots of air temperatures differences for the avenue-tree row scenario (Fig. 12), the facade greening scenario (Fig. 13) and the roof greening scenario (Fig. 14) suggests that the resulting transpirational cooling in the case of all vegetative measures (Fig. 15) resembles that of a linear superposition of the single scenarios. This hypothesis is substantiated by comparing the sum of the mean temperature difference of each scenario with the difference obtained for the scenario with all vegetative measures simultaneously applied which is $-0.40{ }^{\circ} \mathrm{C}$ compared to $-0.39{ }^{\circ} \mathrm{C}$ for the vertical cross sections 1 to 4 and $-0.50{ }^{\circ} \mathrm{C}$ compared to $-0.52{ }^{\circ} \mathrm{C}$ at $2 \mathrm{~m}$ height above ground (Table 1). This indicates that on the street canyon scale the single vegetative measures as applied in the J.P. van Muijlwijkstraat do not strongly interact with each other in terms of the flow and air temperature field. However, this does not necessarily exclude locally restricted non-linear interactions among the vegetative measures as will be shown later.

In order to clarify the transpirational cooling effects of the different vegetative measures, air temperatures at $2 \mathrm{~m}$ height along two paths are shown in Fig. 16. Path 1 is located on the north side of the street canyon and runs approximately below the centerline of the avenue-tree row and path 2 is located in the middle of the street canyon, see Fig. 16. The slight transpirational cooling effect in the status quo due to the existing trees in comparison to the novegetation scenario can be noticed along both paths except for the western part of the J.P. van Muijlwijkstraat where the street canyon is broader. In the eastern canyon part along path 1 , the differences in air temperatures continuously increase in westward direction. The cooler air along path 2 at the eastside is due to the
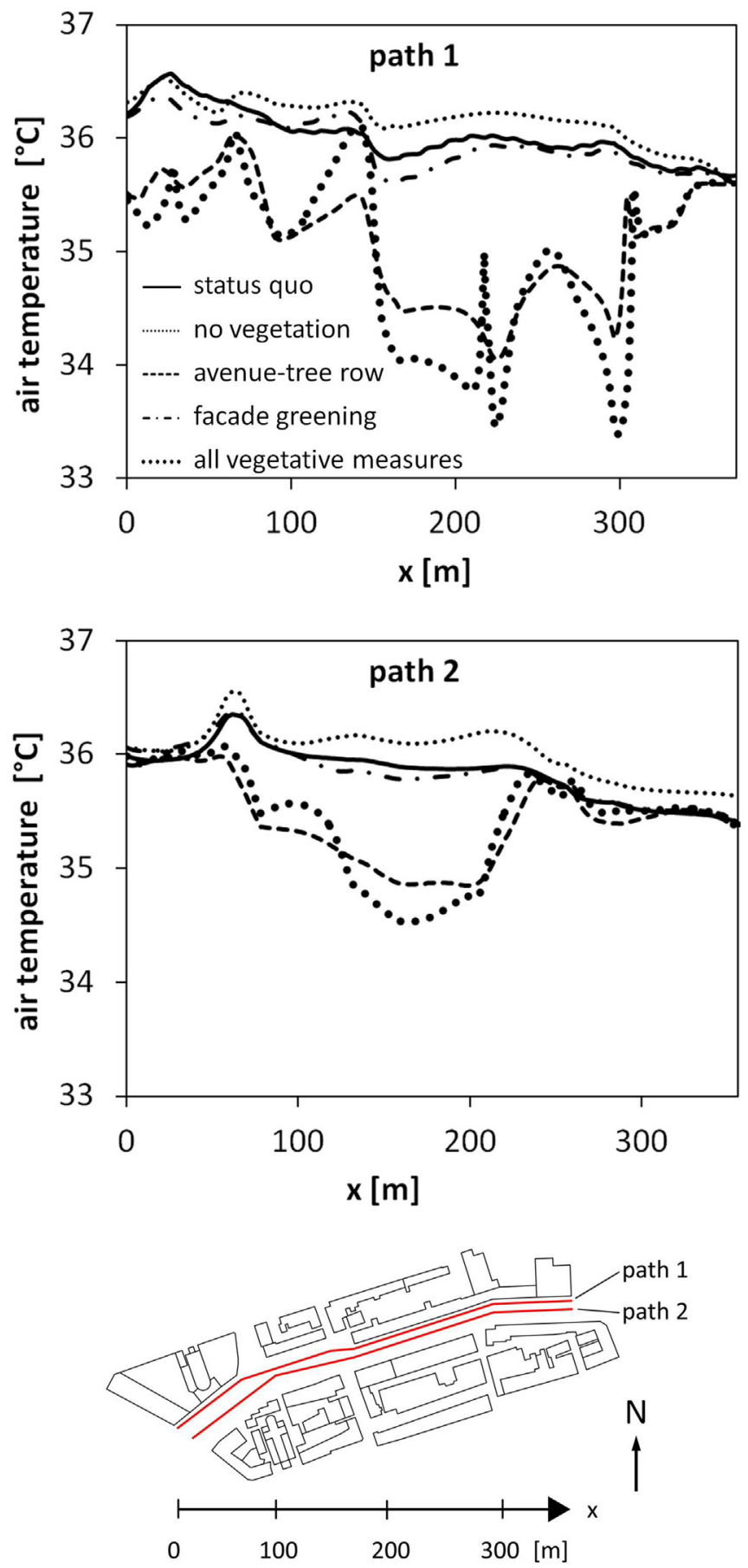

Fig. 16. Air temperatures $\left[{ }^{\circ} \mathrm{C}\right]$ at $2 \mathrm{~m}$ height in front of the northern building walls (path 1) and in the middle of the street canyon (path 2).

patch of trees which is located eastward of the street canyon. The graphs in Fig. 16 substantiate that the avenue-tree row is most effective single vegetative measure in proving transpirational cooling for the street canyon. The stronger temperature reductions occur along path 1 with maximum decreases of approximately $2{ }^{\circ} \mathrm{C}$. However, a distinct cooling effect of around $1{ }^{\circ} \mathrm{C}$ is also present along path 2 except at the western and eastern part of the street canyon. With respect to the facade greening the locally restricted effects on air temperatures close to the building walls are clearly visible. Whereas along path 1 , which is in close vicinity of the facade greening at the north side, slight differences in air 
temperature are visible, only very marginal differences are found along path 2 . The roof greening scenario is not included in the graphs since there were no visible changes in the air temperature at pedestrian level. The scenario with all vegetative measures simultaneously applied roughly follows the avenue-tree row scenario but with generally lower air temperatures. However, some locally restricted prominent deviations are apparent along path 1 . They may be due to the narrowing of the gap between the avenue-tree row and the buildings by the facade greening which affects the local flow conditions in such a manner that the resulting temperature field deviates from a linear superposition of the fields of each vegetative measure.

Overall, the decreases in air temperature were less pronounced at the eastern and western part of the street canyon. The largest transpirational cooling in all scenarios is generally present between $100 \mathrm{~m}<x<300 \mathrm{~m}$. The lower cooling effectiveness in the eastern part is due to the fact that for the present wind direction the air enters the street canyon at this side and is subsequently cooled when flowing through the vegetation. The lower cooling effectiveness in the western part is attributed to the larger canyon width which is here approximately $50 \%$ broader than in the rest of the street. Here, the share of vegetation in the total street canyon volume is smaller and hence the total transpirational cooling effect is lower. Furthermore, the decreases in temperature along path 1 were generally stronger than along path 2 . This substantiates the locally restricted transpirational cooling effect of the applied vegetative measures.

\subsection{Universality and limitations of the present study}

The presented findings on transpirational cooling effects of vegetative measures on air temperatures in a street canyon were obtained by a case study for a certain site and under the specific meteorological conditions of a hot summer day afternoon hour with clear sky during a heat wave with easterly wind aligned with the street canyon along-direction. The question is now, how strong are these findings coupled or restricted to the investigated specific environment and the applied boundary conditions and what can be concluded from this case study in general? In this context, in particular the following questions arise: How will the transpirational cooling effects of the vegetative measures and hence the resulting air temperatures inside the J.P. van Muijlwijkstraat change for different wind directions or approach wind speeds and what is the influence of the leaf area density (LAD)?

In the present study, the approach wind was coming from east and fairly aligned with J.P. van Muijlwijkstraat. For this specific boundary condition, the velocity field is dominated by an advective flow through the street canyon. A characteristically different velocity field will emerge in the canyon if the approach flow is oblique or perpendicular to the street. In these cases, the flow component which is perpendicular to the street is expected to accomplish a transport of air across the street width and reduce the gradients in air temperature between the southern and the northern building walls which were found under the present mean wind direction for the avenue-tree row and facade greening scenario (Figs. 12 and 13, respectively). The resulting temperature distribution is expected to be more homogeneous and the maximum temperature decreases to be less pronounced. Furthermore, a characteristic difference is expected for the transpirational cooling effect of the roof greening. Whereas for the studied mean wind direction no changes in the air temperature were found, except for some marginal cooling in the roof level, it is hypothesized that for perpendicular and oblique wind directions the cooled roof air can get entrained into the street by a canyon vortex and affects, though slightly, the air temperatures at the pedestrian level.
The effect of different approach wind speeds is not straightforward to determine. On the one hand, lower wind velocities imply that an air parcel stays for a longer time within the vegetation volume were it is subjected to cooling. Consequently, calmer air experiences a larger temperature reduction (cf. Eq. (8)) and the average air temperature inside the street canyon decreases. The flow inside the street canyon is more stably stratified. Less convective mixing occurs and in particular the pedestrian level can be expected to benefit from cooler air temperatures. Moreover, in the presence of low wind speed conditions, the air cooled by the roof greening may possibly drain into the street canyon instead of being dispersed into the above roof flow. On the other hand, since the residence time in the street canyon is longer, the air adjacent to hot building and street surfaces is heated up stronger which in turn leads to increased convective mixing. However, the results of this study do not allow to draw final conclusions here, additional simulations with different approach wind speeds are required for clarification.

Finally, the implications of the leaf area density (LAD) are addressed. It is straightforward that a higher leaf area density (LAD) results in larger maximum air temperature reductions within the vegetation and in its close vicinity since the volumetric cooling power of vegetation $P_{\mathrm{c}}$ is proportional to the leaf area density (cf. Eq. (8)). However, due to the increased aerodynamic resistance, the flow field in the canyon is affected and the air mass flux through the vegetation is smaller. Whether or not the air temperatures within the street canyon will be positively affected in the sense of a cooler average temperature and a beneficial redistribution can not be inferred from the present study.

The above considerations on the implications of different boundary conditions on air temperatures inside the J.P. van Muijlwijkstraat imply that special care is required before generalization of the quantitative results from this study. This will require additional comprehensive simulations with varying conditions. Hence, the herein presented findings and their applicability have to be seen in the frame of the underlying specific site and meteorological conditions. They do not allow for a universally valid quantification of the transpirational cooling potential of vegetative measures as a climate change adaptation measure in urban areas.

It is important to note that the simulations with the applied volumetric cooling powers $P_{\mathrm{c}}$ for the different vegetative measures are based on the condition of unlimited water supply. In the case of limited water supply or water stress, the transpirational flux from the leaf surfaces is reduced and hence the cooling is also reduced (e.g. Refs. [87,88]). This implies for most locations a regular irrigation of the vegetation in order to maintain the cooling effect during summer periods and in particular during heat waves. Furthermore, it is recalled that within the present study the transpirational cooling effect of vegetative measures was investigated in an isolated way. Next to this, vegetation affects urban air temperatures also by shading, by trapping reflected short and long-wave radiation, by higher short-wave reflectivities and lower heat capacities compared to building surfaces and materials. All these effects, and in particular shading of direct solar radiation, impact the thermal comfort within the urban environment, which is however beyond the scope of this study. With respect to the pure shading effect of trees, Andreou [92] obtained for a street canyon with east-west orientation daily maximum reductions in surface temperatures of $7{ }^{\circ} \mathrm{C}$ which resulted in maximum air temperature reductions of $1.5^{\circ} \mathrm{C}$. However, given the relative orientations of the sun, the trees and the buildings at the north side of the J.P. van Muijlwijkstraat (Figs. 7 and 11), it is hypothesized that because of the large angle of incidence of solar rays at the building facades, the differences in surface and air temperatures due to the shading effect will be less. At the end of the discussion it is appropriate to consider the 
presented study in a broader urban micrometeorological and microclimatological context. The effects of vegetation on the urban microclimate and micrometeorology are multifold [2]. Next to the effect on air temperature, vegetation also affects the flow conditions within the urban canopy. This has implications on the dispersion of pollutants and wind comfort at pedestrian level. Recent studies show that avenue-trees in urban street canyons in general reduce their natural ventilation and hence lead to higher traffic pollutant concentrations, e.g. Refs. [93-102]. At the same time, vegetation can be instrumentalized to reduce wind speeds within the urban canopy layer and help to create better wind comfort conditions. (e.g. Refs. [26,28]). Vegetation in the urban environment can simultaneously be beneficial in terms of some aspects but detrimental in terms of others. The herein studied effect on air temperature is only a partial aspect and has to be balanced against other aspects for a sustainable urban design.

\section{Conclusions and recommendations}

The case study for the J.P. van Muijlwijkstraat in the Dutch city of Arnhem showed that locally applied vegetative measures at the street and building scale can contribute to a reduction of air temperatures in urban street canyons during hot summer days by transpirational cooling. The intensity of cooling in terms of air temperature reductions and their spatial extent differed distinctly between the various vegetative measures. Vegetative measures which were applied inside the street canyon such as avenue-trees or facade greening had a noticeable effect on the transpirational cooling of air within the canyon and at the pedestrian level, whereas roof greening which was applied outside the street canyon had not. The avenue-trees provided a marked transpirational cooling within the street canyon both in terms of air temperature reductions and spatial extent. The strongest reductions of $1.6^{\circ} \mathrm{C}$ in air temperature were found inside and directly next to the tree crowns. An effect of the facade greening on the air temperatures in the street canyon was also noticeable but relatively small compared to the avenue-trees and locally restricted to the vicinity of the building walls where maximum reductions of up to $0.5{ }^{\circ} \mathrm{C}$ were found. In the center of the street canyon no transpirational cooling effect by facade greening was found. The locally applied roof greening did not influence the air temperatures inside the canyon in the present situation with wind parallel to the street. The air cooled by the roof greening was rather dispersed into the above roof flow than entrained into the street canyon. However, for perpendicular or oblique winds, or under low wind conditions, the cooled roof top air may get entrained into the street canyon and result in noticeable air temperature reductions. The combination of all vegetative measures showed the largest impact on air temperatures with a maximum local decrease of $2.0{ }^{\circ} \mathrm{C}$. Overall, the resulting temperature field inside the street canyon resembled that of a linear superposition of those from the single vegetative measures. The results of this study are corroborated by other literature [15-18] as has been detailed in the result section (Section 3). Although the representativeness of this case study is limited and has to be seen in the light of the modeling and meteorology specific boundary conditions, the findings suggest to apply vegetative measures inside urban street canyons as a climate change adaptation measure since noticeable reductions in air temperatures can be realized by transpirational cooling. The combination of avenuetrees together with facade greening is most promising. Avenuetrees are to prefer over facade greening because their overall transpirational cooling effect is much stronger due to their larger vegetation volume and leaf biomass. In particular avenue-tree rows on both sides of a street appear very promising since in this manner a large vegetation volume and leaf biomass inside the canyon can be realized. For the same reason, tree species with tall and broad crowns are preferable and a noticeable increase in transpirational cooling compared to this case study, where the tree crowns with $5 \mathrm{~m}$ width and $6 \mathrm{~m}$ height are rather small, may be expected. Since the study clearly showed that the transpirational cooling effect was in general locally restricted to the close vicinity of the vegetation and to the street canyon itself, a spatially extensive and noticeable transpirational cooling requires a densely distributed arrangement of vegetative measures in order to achieve a city wide air temperature reduction. This implies the arrangement of vegetative measures along many streets and squares and also in courtyards. Finally, it is important to note that vegetation can provide transpirational cooling only if the water vapor flux from the leaf surfaces is not or not significantly limited due to water shortage. In order to avoid this condition, a regular irrigation will be needed in most places of the world during hot summers or heat waves.

\section{Acknowledgments}

The research was supported by the Dutch Knowledge for Climate Research Program within the theme Climate Proof Cities (CPC). Christof Gromke was supported by a Marie Curie Intra European Fellowship (276324 (VEGAIR)) within the 7th European Community Framework Programme. The authors would like to thank Evyatar Erell from the Ben Gurion University of the Negev (Israel) for kindly providing measurement data and supportive discussions.

\section{References}

[1] Van den Hurk B, Klein Tank A, Lenderink G, van Ulden A, Van Oldenborgh GJ, Katsman C, et al. KNMI climate change scenarios 2006 for the Netherlands. KNMI De Bilt; 2006.

[2] Oke TR. The energetic basis of the urban heat island. Q J R Meteorol Soc $1982 ; 108: 1-24$.

[3] Taha H. Urban climates and heat islands: albedo, evapotranspiration, and anthropogenic heat. Energy Build 1997;25:99-103.

[4] Arnfield AJ. Two decades of urban climate research: a review of turbulence, exchanges of energy and water, and the urban heat island. Int J Climatol 2003;23:1-26.

[5] Wilby RL. Past and projected trends in London's urban heat island. Weather 2003;58:251-60

[6] Heusinkveld BG, Steeneveld GJ, Hove LWA, Jacobs CMJ, Holtslag AAM. Spatial variability of the Rotterdam urban heat island as influenced by urban land use. J Geophys Res Atmosp 2014;119:667-92.

[7] Steeneveld GJ, Koopmans S, Heusinkveld BG, Van Hove LWA, Holtslag AAM Quantifying urban heat island effects and human comfort for cities of variable size and urban morphology in the Netherlands. J Geophys Res 2011;116: D20129.

[8] Sanders CH, Phillipson MC. UK adaptation strategy and technical measures: the impacts of climate change on buildings. Build Res Inf 2003;31:210-21.

[9] Wilby RL. A review of climate change impacts on the built environment. Built Environ 2007;33:31-45.

[10] Daanen HAM., Herweijer J. Effectiveness of an indoor preparation program to increase thermal resilience in elderly for heat waves. [Submitt Spec Issue Clim Adapt Cities Build Environ n.d].

[11] Garssen J, Harmsen C, De Beer J. The effect of the summer 2003 heat wave on mortality in the Netherlands. Eurosurveillance 2005;10:165-7.

[12] Bowler DE, Buyung-Ali L, Knight TM, Pullin AS. Urban greening to cool towns and cities: a systematic review of the empirical evidence. Landsc Urban Plan 2010;97:147-55.

[13] Akbari H, Bretz S, Kurn DM, Hanford J. Peak power and cooling energy savings of high-albedo roofs. Energy Build 1997;25:117-26.

[14] Nishimura N, Nomura T, Iyota H, Kimoto S. Novel water facilities for creation of comfortable urban micrometeorology. Sol Energy 1998;64:197-207.

[15] Wong NH, Chen Y, Ong CL, Sia A. Investigation of thermal benefits of rooftop garden in the tropical environment. Build Environ 2003;38:261-70.

[16] Dimoudi A, Nikolopoulou M. Vegetation in the urban environment: microclimatic analysis and benefits. Energy Build 2003;35:69-76.

[17] Alexandri E, Jones P. Temperature decreases in an urban canyon due to green walls and green roofs in diverse climates. Build Environ 2008:43:480-93.

[18] Wong NH, Kwang Tan AY, Chen Y, Sekar K, Tan PY, Chan D, et al. Thermal evaluation of vertical greenery systems for building walls. Build Environ 2010;45:663-72. 
[19] Fröhlich D, Matzarakis A. Modeling of changes in thermal bioclimate: examples based on urban spaces in Freiburg, Germany. Theor Appl Climatol 2013;111:547-58.

[20] Bruse M, Fleer H. Simulating surface-plant-air interactions inside urban environments with a three dimensional numerical model. Environ Model Softw 1998; 13:373-84.

[21] Ali-Toudert F, Mayer H. Effects of asymmetry, galleries, overhanging facades and vegetation on thermal comfort in urban street canyons. Sol Energy 2007;81:742-54.

[22] Takahashi K, Yoshida H, Tanaka Y, Aotake N, Wang F. Measurement of thermal environment in Kyoto city and its prediction by CFD simulation. Energy Build 2004;36:771-9.

[23] Höppe P. The physiological equivalent temperature - a universal index for the biometeorological assessment of the thermal environment. Int J Biometeorol 1999;43:71-5.

[24] Bröde P, Fiala D, Błażejczyk K, Holmér I, Jendritzky G, Kampmann B, et al. Deriving the operational procedure for the Universal Thermal Climate Index (UTCI). Int J Biometeorol 2012;56:481-94.

[25] Intergovernmental Panel on Climate Change (IPCC). Climate change 2007: impacts, adaptation and vulnerability. Cambridge: Cambridge University Press; 2007.

[26] Blocken B, Stathopoulos T. CFD simulation of pedestrian-level wind conditions around buildings: past achievements and prospects. J Wind Eng Ind Aerodyn 2013;121:138-45.

[27] Janssen WD, Blocken B, van Hooff T. Pedestrian wind comfort around buildings: comparison of wind comfort criteria based on whole-flow field data for a complex case study. Build Environ 2013:59:547-62.

[28] Mochida A, Lun IY. Prediction of wind environment and thermal comfort at pedestrian level in urban area. J Wind Eng Ind Aerodyn 2008;96:1498-527.

[29] Montazeri H, Blocken B, Janssen WD, van Hooff T. CFD evaluation of new second-skin facade concept for wind comfort on building balconies: case study for the Park Tower in Antwerp. Build Environ 2013;68:179-92.

[30] Yoshie R, Mochida A, Tominaga Y, Kataoka H, Harimoto K, Nozu T, et al. Cooperative project for CFD prediction of pedestrian wind environment in the Architectural Institute of Japan. J Wind Eng Ind Aerodyn 2007;95: $1551-78$.

[31] Blocken B. 50 years of computational wind engineering: past, present and future. J Wind Eng Ind Aerodyn 2014;129:69-102.

[32] Tominaga Y, Stathopoulos T. CFD simulation of near-field pollutant dispersion in the urban environment: a review of current modeling techniques. Atmos Environ 2013;79:716-30.

[33] Blocken B, Stathopoulos T, Saathoff P, Wang X. Numerical evaluation of pollutant dispersion in the built environment: comparisons between models and experiments. J Wind Eng Ind Aerodyn 2008;96:1817-31.

[34] Hanna SR, Brown MJ, Camelli FE, Chan ST, Coirier WJ, Kim S, et al. Detailed simulations of atmospheric flow and dispersion in downtown Manhattan: an application of five computational fluid dynamics models. Bull Am Meteoro Soc 2006;87:1713-26.

[35] Gousseau P, Blocken B, Stathopoulos T, Van Heijst GJF. CFD simulation of near-field pollutant dispersion on a high-resolution grid: a case study by LES and RANS for a building group in downtown Montreal. Atmos Environ 2011;45:428-38.

[36] Neofytou P, Haakana M, Venetsanos A, Kousa A, Bartzis J, Kukkonen J. Computational fluid dynamics modelling of the pollution dispersion and comparison with measurements in a street canyon in Helsinki. Environ Model Assess 2008;13:439-48.

[37] Blocken B, Carmeliet J. A review of wind-driven rain research in building science. J Wind Eng Ind Aerodyn 2004;92:1079-130.

[38] Blocken B, Carmeliet J. The influence of the wind-blocking effect by a building on its wind-driven rain exposure. J Wind Eng Ind Aerodyn 2006;94:101-27.

[39] Choi ECC. Simulation of wind-driven-rain around a building. J Wind Eng Ind Aerodyn 1993;46:721-9.

[40] Kubilay A, Derome D, Blocken B, Carmeliet J. CFD simulation and validation of wind-driven rain on a building facade with an Eulerian multiphase model. Build Environ 2013;61:69-81.

[41] Toparlar Y, Blocken B, Vos P, Janssen W, van Hooff T, Montazeri H, et al. CFD simulation and validation of urban microclimate: a case study for Bergpolder Zuid, Rotterdam. Build Environ 2015;83:79-90.

[42] Panagiotou I, Neophytou MK-A, Hamlyn D, Britter RE. City breathability as quantified by the exchange velocity and its spatial variation in real inhomogeneous urban geometries: an example from central London urban area. Sci Total Environ 2013;442:466-77.

[43] Ramponi R, Blocken B. CFD simulation of cross-ventilation for a generic isolated building: impact of computational parameters. Build Environ 2012;53:34-48.

[44] Ramponi R, Blocken B. CFD simulation of cross-ventilation flow for differen isolated building configurations: validation with wind tunnel measurements and analysis of physical and numerical diffusion effects. J Wind Eng Ind Aerodyn 2012;104:408-18.

[45] Mistriotis A, Briassoulis D. Numerical estimation of the internal and external aerodynamic coefficients of a tunnel greenhouse structure with openings Comput Electron Agric 2002;34:191-205.

[46] Buccolieri R, Sandberg M, Di Sabatino S. City breathability and its link to pollutant concentration distribution within urban-like geometries. Atmos Environ 2010;44:1894-903.
[47] Montazeri H. Experimental and numerical study on natural ventilation performance of various multi-opening wind catchers. Build Environ 2011;46:370-8

[48] Montazeri H, Montazeri F, Azizian R, Mostafavi S. Two-sided wind catcher performance evaluation using experimental, numerical and analytical modeling. Renew Energy 2010;35:1424-35.

[49] Allegrini J, Dorer V, Carmeliet J. Buoyant flows in street canyons: validation of CFD simulations with wind tunnel measurements. Build Environ 2014;72: $63-74$

[50] Moonen P, Defraeye T, Dorer V, Blocken B, Carmeliet J. Urban physics: effect of the micro-climate on comfort, health and energy demand. Front Archit Res 2012; 1:197-228.

[51] Ashie Y, Thanh Ca V, Asaeda T. Building canopy model for the analysis of urban climate. J Wind Eng Ind Aerodyn 1999;81:237-48.

[52] Ca VT, Asaeda T, Ashie Y. Development of a numerical model for the evaluation of the urban thermal environment. J Wind Eng Ind Aerodyn 1999;81: 181-96.

[53] Li X, Yu Z, Zhao B, Li Y. Numerical analysis of outdoor thermal environment around buildings. Build Environ 2005;40:853-66.

[54] Albers RAW, Blocken B, Bosch PR. Overview of challenges and achievements in the climate proof cities program. Build Environ 2015;83:1-10.

[55] Knowledge for climate. Climate proof cities; 2013.

[56] Franke J, Hellsten A, Schlünzen H, Carissimo B. Best practice guideline for the CFD simulation of flows in the urban environment. Cost Action 2007;732:51.

[57] Franke J, Hellsten A, Schlunzen KH, Carissimo B. The COST 732 best practice guideline for CFD simulation of flows in the urban environment: a summary. Int J Environ Pollut 2011:44:419-27.

[58] Tominaga Y, Mochida A, Yoshie R, Kataoka H, Nozu T, Yoshikawa M, et al. AIJ guidelines for practical applications of CFD to pedestrian wind environment around buildings. J Wind Eng Ind Aerodyn 2008;96:1749-61.

[59] Blocken B, Gualtieri C. Ten iterative steps for model development and evaluation applied to computational fluid dynamics for environmental fluid mechanics. Environ Model Softw 2012;33:1-22.

[60] Van Hooff T, Blocken B. Coupled urban wind flow and indoor natural ventilation modelling on a high-resolution grid: a case study for the Amsterdam ArenA stadium. Environ Model Softw 2010;25:51-65.

61] Hooff T van, Blocken B. On the effect of wind direction and urban surroundings on natural ventilation of a large semi-enclosed stadium. Comput Fluids 2010;39:1146-55.

[62] Blocken B, Janssen WD, van Hooff T. CFD simulation for pedestrian wind comfort and wind safety in urban areas: general decision framework and case study for the Eindhoven University campus. Environ Model Softw 2012;30:15-34.

[63] ANSYS. ANSYS FLUENT 12.0 manual. ANSYS Inc; 2009.

[64] Shih T-H, Liou WW, Shabbir A, Yang Z, Zhu J. A new k-eddy viscosity model for high Reynolds number turbulent flows. Comput Fluids 1995;24:227-38.

[65] Siegel R, Howell JR. Thermal radiation heat transfer. Wash DC: Hemisphere Pub. Corp.; 1992.

[66] Wieringa J. Updating the Davenport roughness classification. J Wind Eng Ind Aerodyn 1992;41:357-68.

[67] Blocken B, Stathopoulos T, Carmeliet J. CFD simulation of the atmospheric boundary layer: wall function problems. Atmos Environ 2007:41:238-52.

[68] Blocken B, Carmeliet J, Stathopoulos T. CFD evaluation of wind speed conditions in passages between parallel buildings-effect of wall-function roughness modifications for the atmospheric boundary layer flow. J Wind Eng Ind Aerodyn 2007;95:941-62.

[69] Richards PJ, Hoxey RP. Appropriate boundary conditions for computational wind engineering models using the k-turbulence model. J Wind Eng Ind Aerodyn 1993:46:145-53.

[70] Launder BE, Spalding DB. The numerical computation of turbulent flows. Comput Methods Appl Mech Eng 1974;3:269-89.

[71] Cebeci T, Bradshaw P. Momentum transfer in boundary layers. Wash DC Hemisphere Publ Corp N Y McGraw-Hill Book Co; 1977. p. 407. 1.

[72] Handbook A. ASHRAE handbook - fundamentals; 2009. Atlanta GA.

[73] Oke TR. Boundary layer climates; 1987.

[74] Santamouris M. Energy and climate in the urban built environment; 2001. Routledge.

[75] Green SR. Modelling turbulent air flow in a stand of widely-spaced trees. Phoenics J 1992; 5:294-312.

[76] Liu J, Chen JM, Black TA, Novak MD. E- $\varepsilon$ modelling of turbulent air flow downwind of a model forest edge. Bound-layer Meteorol 1996;77:21-44.

[77] Sanz C. A note on k- $\varepsilon$ modelling of vegetation canopy air-flows. Bound-layer Meteorol 2003;108:191-7.

[78] Katul GG, Mahrt L, Poggi D, Sanz C. One-and two-equation models for canopy turbulence. Bound-layer Meteorol 2004;113:81-109.

[79] Green SR, Grace J, Hutchings NJ. Observations of turbulent air flow in three stands of widely spaced Sitka spruce. Agric Meteorol 1995;74:205-25.

[80] Wilson NR, Shaw RH. A higher order closure model for canopy flow. J Appl Meteorol 1977:16:1197-205.

[81] Defraeye T, Herremans E, Verboven P, Carmeliet J, Nicolai B. Convective heat and mass exchange at surfaces of horticultural products: a microscale CFD modelling approach. Agric Meteorol 2012;162:71-84.

[82] Defraeye T, Verboven P. Derome D, Carmeliet J, Nicolai B. Stomatal transpiration and droplet evaporation on leaf surfaces by a microscale modelling approach. Int J Heat Mass Transf 2013;65:180-91. 
[83] Incropera FP, Lavine AS, DeWitt DP. Fundamentals of heat and mass transfer. John Wiley \& Sons Incorporated; 2011.

[84] Amiro BD. Comparison of turbulence statistics within three boreal forest canopies. Bound-layer Meteorol 1990;51:99-121.

[85] ANSYS. ANSYS FLUENT 12.0 UDF manual. ANSYS Inc; 2009.

[86] Rahman MA, Smith JG, Stringer P, Ennos AR. Effect of rooting conditions on the growth and cooling ability of Pyrus calleryana. Urban Urban Green 2011;10:185-92.

[87] Shashua-Bar L, Pearlmutter D, Erell E. The cooling efficiency of urban landscape strategies in a hot dry climate. Landsc Urban Plan 2009;92:179-86.

[88] Shashua-Bar L, Pearlmutter D, Erell E. The influence of trees and grass on outdoor thermal comfort in a hot-arid environment. Int J Climatol 2011;31: 1498-506.

[89] Breuer L, Eckhardt K, Frede H-G. Plant parameter values for models in temperate climates. Ecol Model 2003;169:237-93.

[90] Susorova I, Angulo M, Bahrami P, Stephens B. A model of vegetated exterior facades for evaluation of wall thermal performance. Build Environ 2013;67: $1-13$.

[91] Barrio EPD. Analysis of the green roofs cooling potential in buildings. Energy Build 1998;27:179-93.

[92] Andreou E. The effect of urban layout, street geometry and orientation on shading conditions in urban canyons in the Mediterranean. Renew Energy 2014:63:587-96.

[93] Gromke C, Ruck B. Influence of trees on the dispersion of pollutants in an urban street canyon-experimental investigation of the flow and concentration field. Atmos Environ 2007;41:3287-302.

[94] Gromke C, Buccolieri R, Di Sabatino S, Ruck B. Dispersion study in a street
- evaluation of CFD data with experimental data. Atmos Environ 2008;42: $8640-50$.

[95] Balczo M, Gromke C, Ruck B. Numerical modeling of flow and pollutant dispersion in street canyons with tree planting. Meteorol Z 2009;18:197206.

[96] Buccolieri R, Salim SM, Leo LS, Di Sabatino S, Chan A, Ielpo P, et al. Analysis of local scale tree-atmosphere interaction on pollutant concentration in idealized street canyons and application to a real urban junction. Atmos Environ 2011;45:1702-13.

[97] Salim SM, Cheah SC, Chan A. Numerical simulation of dispersion in urban street canyons with avenue-like tree plantings: comparison between RANS and LES. Build Environ 2011;46:1735-46.

[98] Gromke C. A vegetation modeling concept for building and environmental aerodynamics wind tunnel tests and its application in pollutant dispersion studies. Environ Pollut 2011;159:2094-9.

[99] Gromke C, Ruck B. Pollutant concentrations in street canyons of differen aspect ratio with avenues of trees for various wind directions. Bound-layer Meteorol 2012;144:41-64.

[100] Moonen P, Gromke C, Dorer V. Performance assessment of Large Eddy Simulation (LES) for modeling dispersion in an urban street canyon with tree planting. Atmos Environ 2013;75:66-76.

[101] Salmond JA, Williams DE, Laing G, Kingham S, Dirks K, Longley I, et al. The influence of vegetation on the horizontal and vertical distribution of pollutants in a street canyon. Sci Total Environ 2013;443:287-98.

[102] Vos PE, Maiheu B, Vankerkom J, Janssen S. Improving local air quality in cities: to tree or not to tree? Environ Pollut 2013;183:113-22. 